\title{
How to manage uncertainty in future Life Cycle Assessment (LCA) scenarios addressing the effect of climate change in crop production
}

Niero, Monia; Ingvordsen, Cathrine Heinz; Bagger Jørgensen, Rikke; Hauschild, Michael Zwicky

Published in:

Journal of Cleaner Production

Link to article, DOI:

10.1016/j.jclepro.2015.05.061

Publication date:

2015

Document Version

Peer reviewed version

Link back to DTU Orbit

Citation (APA):

Niero, M., Ingvordsen, C. H., Bagger Jørgensen, R., \& Hauschild, M. Z. (2015). How to manage uncertainty in future Life Cycle Assessment (LCA) scenarios addressing the effect of climate change in crop production. Journal of Cleaner Production, 107, 693-706. https://doi.org/10.1016/j.jclepro.2015.05.061

\section{General rights}

Copyright and moral rights for the publications made accessible in the public portal are retained by the authors and/or other copyright owners and it is a condition of accessing publications that users recognise and abide by the legal requirements associated with these rights.

- Users may download and print one copy of any publication from the public portal for the purpose of private study or research.

- You may not further distribute the material or use it for any profit-making activity or commercial gain

- You may freely distribute the URL identifying the publication in the public portal 


\title{
How to manage uncertainty in future LCA scenarios addressing the effect of climate change in crop production
}

\author{
Monia Niero ${ }^{\mathrm{a}, \mathrm{b}, \S}$, Cathrine Heinz Ingvordsen ${ }^{\mathrm{b} 1}$, Rikke Bagger Jørgensen ${ }^{\mathrm{b}}$, Michael Zwicky Hauschild ${ }^{\mathrm{a}}$ \\ ${ }^{a}$ QSA - Quantitative Sustainability Assessment Division, Department of Management Engineering, \\ Technical University of Denmark, Produktionstorvet 424 DK-2800 Kgs. Lyngby. Email: monni@dtu.dk \\ ${ }^{\mathrm{b}}$ ECO - Center for Ecosystem and Environmental Sustainability, Department of Chemical and Biochemical \\ Engineering, Technical University of Denmark, Frederiksborgvej 399, DK-4000 Roskilde \\ ${ }^{\S}$ Corresponding author
}

E-mail addresses: C.H. Ingvordsen (cathrine.ingvordsen@ csiro.au); Rikke B. Jørgensen (rijq@kt.dtu.dk); Michael Z. Hauschild (mzha@dtu.dk)

${ }^{1}$ Current address: CSIRO, Black Mountain Laboratories, GPO Box 1600, Canberra, ACT, 2601, Australia

\begin{abstract}
When Life Cycle Assessment (LCA) is used to provide insights on how to pursue future food demand, it faces the challenge to describe scenarios of the future in which the environmental impacts occur. In the case of future crop production, the effects of climate change should be considered. In this context, the objectives of this paper are two-fold: (i) to recommend an approach to deal with uncertainty in scenario analysis for LCA of crop production in a changed climate, when the goal of the study is to suggest strategies for adaptation of crop cultivation practices towards low environmental impacts, and (ii) to implement the suggested approach to spring barley cultivation in Denmark. First, the main implications of climate change for future crop cultivation are analyzed, and the factors which should be included when modeling the climate change effects on crops through LCA are introduced, namely climate, soil, water loss and production parameters. Secondly, the handling of these factors in the inventory modelling is discussed and finally implemented in the case study. Our approach follows a 3-step procedure consisting of: (1) definition of a baseline scenario at the Life Cycle Inventory (LCI) level for the selected crop and performance of Life Cycle Impact Assessment (LCIA) including normalization and contribution analysis, in order to identify the focus points in terms of impact categories, unit processes and substances; (2) identification of the main deviations from the baseline scenario for these key parameters in alternative future scenarios; (3) comparison of the different scenarios including quantification of the uncertainty at inventory level.

The procedure presented was successfully implemented to assess the consequences of the changed climate on Danish spring barley cultivated under future climate conditions. The LCA results, obtained using mainly primary data from phytotron experiments mimicking a future Danish climate, emphasized that adaptation strategies should prioritize the development of resilient and stable cultivars, i.e. robust to the expected extremes of the future climate and offering a reasonable yield under different climatic conditions.
\end{abstract}

Keywords (max 6): LCI, primary data, scenario analysis, hotspot analysis, normalization, uncertainty analysis 


\section{Highlights:}

- Main implications of climate change for crop production are discussed

- We suggest how to develop future LCA scenarios for crops in a changed climate

- 3-step procedure based on scenario analysis is tested with Danish spring barley

- Production data from phytotron-facility mimicking future climate conditions are used

- LCA stressed that adaptation should aim for breeding stable and resilient cultivars

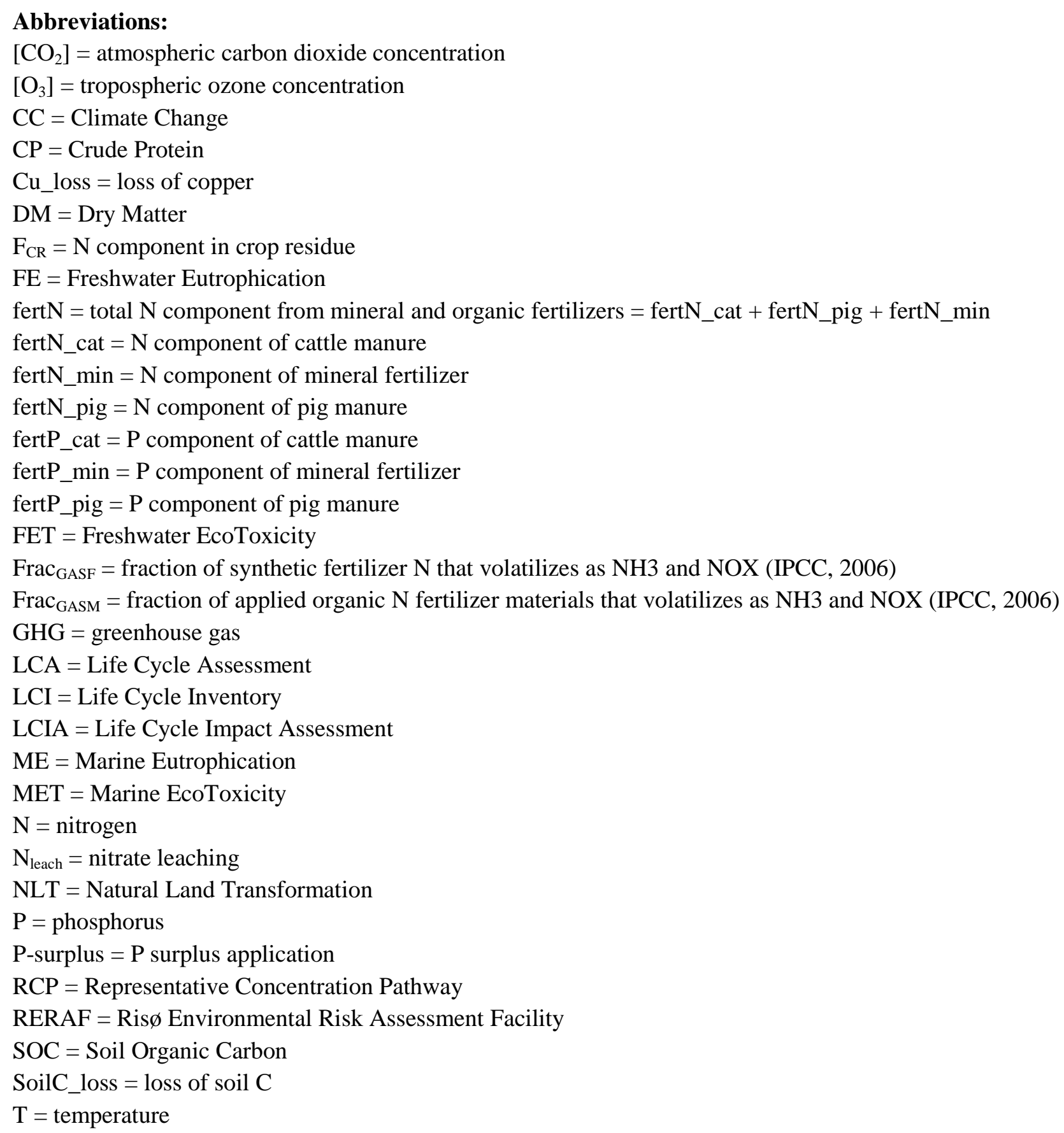




\section{Introduction}

Agriculture, including crop and livestock production, forestry and other land uses is responsible for about one quarter of the total emissions on a world basis, which makes it one of the most contributing sectors to the net anthropogenic greenhouse gas (GHG) emissions (IPCC, 2014a). Guaranteeing a substantial growth of primary production while limiting agriculture's environmental footprint is among the priorities in international agricultural policy agendas (Alexandratos and Bruinsma, 2012). The environmental impacts of agriculture are correlated to both expansion, when croplands and pastures extend into new areas replacing natural ecosystems, and to intensification, when existing lands are managed to be more productive (Foley et al., 2011). Agricultural expansion and intensification are major contributors not just to climate change but also biodiversity loss, nutrient emissions, and freshwater and land degradation (Rockström et al., 2009). In the past years mainly expansion has been investigated, but bringing new land into cultivation proved to cause a lot of side effects, e.g. due to deforestation and loss of biodiversity in rain forests. Therefore the opportunity provided by the so-called "sustainable intensification", i.e. producing more food from the same area of land while reducing the environmental impacts, is nowadays given high priority (Godfray et al., 2010).

One of the most effective tools to quantify the potential environmental impacts of product systems, including agricultural systems, is Life Cycle Assessment (LCA). As pointed out by Soussana (2014) LCA can play an important role in designing sustainable agri-food systems, but it needs to overcome several challenges connected with the inclusion of ecosystem services as well as spatial and temporal issues. Temporal issues become relevant when LCA results are used for strategic long term decisions at the agricultural policy level, since LCA faces the challenge to describe scenarios of the future in which the environmental impacts will occur. The definition of future agricultural systems is inherently controversial, as many uncertain and unknown aspects need to be addressed, e.g. the effects of climate change on future crop production, the development of new pesticides, and the possible geographical redistribution of crops according to the most favorable climate.

Scenario analysis is a defined technique in the LCA context, which can provide effective support in handling these challenges. Scenario analysis in LCA deals with three aspects: definition of alternative future circumstances, path from the present to these future circumstances and inclusion of uncertainty about the future (Pesonen et al., 2000). Even though the issue of scenario development has been widely considered in LCA (Höjer et al., 2008), the discussion has mainly been focused on the implications at data modelling level so far, e.g. the choice between attributional and consequential modelling, (e.g. De Camillis et al., 2013; Plevin et al., 2014; Suh and Yang, 2014). With regard to practical applications of future-oriented scenarios, the systems that have been studied are often complex and come from sectors like waste management and energy (Frischknecht et al., 2009; Münster et al., 2013), transportation (Spielmann et al., 2005), and industry (Cluzel et al., 2013). In the agricultural and food sectors, with the exception of one study addressing the challenges connected with scenario definition in LCA for novel food products (Hospido et al., 2009), the focus of future-oriented scenarios has mainly been on comparison of different options to mitigate GHG emissions in the crop, livestock and bioenergy sectors (Audsley and Wilkinson, 2014; González-García et al., 2012) or comparison of different options for future food supply considering drivers and constraints within developments in technology, economy, population, policy and resource scarcity (Odegard and van der Voet, 2014; Röder et al., 2014).

Changes in climate have already caused impacts on natural and human systems, including food production, and according to previsions will have an influence also in the future (IPCC, 2013). Therefore, studies focusing on how to pursue future food security and demand should not neglect the effect of climate change on agricultural production. For crops, the overall relationship between climate conditions and crop productivity is crop- and region- specific, since it depends on differences in baseline climate, management 
and soil, and the duration and timing of crop exposure to various conditions (Porter et al., 2014). One of the regions which is supposed to benefit from the effect of climate change is Northern Europe (Trnka et al., 2011). Many studies have been performed to project climate change impacts on crop productivity for cereals, mainly wheat, barley and oat in Scandinavia (Doltra et al., 2012; Olesen, 2008; Rötter et al., 2012; Rötter et al., 2011). Recently there has also been a growing interest in the assessment of the potential environmental impacts of grain production in this region, e.g. Norway (Korsaeth et al., 2014; Roer et al., 2012) and Finland (Virtanen and Sinkko, 2012). However, little attention has been paid to the effect of climate change on future agricultural production from a comprehensive environmental point of view, and only one LCA study comparing spring barley production under current (2010) and future (2050) climate circumstances has been performed under Danish conditions (Dijkman, 2013). However, Dijkman (2013) uses only partially primary data and does not consider how different adaptation measures can reduce the potential environmental impacts of future spring barley production. The use of LCA as a decision support tool in future policy making needs to overcome one important drawback connected with the reliability of LCA outcomes, i.e. availability of reliable data, particularly on future yields. The influence of data variability at the Life Cycle Inventory (LCI) level is highly relevant in the context of agricultural LCA and has already been addressed with regard to various current agricultural production systems (Basset-Mens et al., 2009; Hayashi et al., 2014; Langevin et al., 2010; Middelaar et al., 2012). Guidance on how to develop consistent LCI data in the agri-food sector as well as on the selection of methodological approach on issues like emission models at the farm level, land use change, water use, pesticides application, have recently been published in the context of the World Food LCA Database (Nemecek et al., 2014), Agri-footprint Database (Blonk Agri-footprint BV, 2014) and Agribalyse (Colomb et al., 2014). However, these initiatives are mainly intended to promote transparency of LCI data and enable comparability of LCA results of current agricultural production systems. In the case of future agricultural systems, primary data from field experiments are not available, since the effect of climate change can only be simulated, either through experimental facilities mimicking the future climate or crop simulation models. According to the review performed by White et al. (2011) on 221 peerreviewed papers that used crop simulation models to examine diverse aspects of how climate change might affect agricultural systems, wheat, maize, soybean and rice are the crops mainly studied among cereals. Spring barley has been much less considered in crop modeling, and accordingly models for barley were developed with less experimental data than those for the above-mentioned cereals. Therefore the uncertainties in simulation results for barley are higher (Rötter et al., 2012). One of the research needs pointed out by Rötter et al. (2011) regards the generation and compilation of high-quality field data for model testing. It is the aim of this paper to provide guidance on how to manage uncertainty in the definition of future LCA scenarios addressing the effect of climate change in crop production, focusing on the relevance of experimental data coming from cultivation facilities mimicking the conditions under a future climate. The objectives of this paper are two-fold:

1. to recommend an approach for scenario analysis of LCA for crop production in a changed climate, when the purpose is to suggest strategies for adaptation of crop cultivation practices towards low environmental impacts in the future;

2. to implement the suggested approach to spring barley cultivation in Denmark under a future realistic worst case climate scenario. 


\section{Materials and methods}

\subsection{Implications of climate change on crop production}

This first section summarizes the main implications of climate change on crop production, and therefore introduces the parameters which should be included when modelling the climate change effects on crop production through LCA. The main source of information is the last published report by the Intergovernmental Panel on Climate Change (IPCC), i.e. the Fifth Assessment report (AR5) which provides an up to date review of the current state of scientific knowledge on climate change and its possible effects (Collins et al., 2013).

The IPCC AR5 and Olesen et al. (2011) identify two different pathways (direct and an indirect) for climate change to affect agricultural crop production. Direct pathways include the effects of change in abiotic factors such as atmospheric $\mathrm{CO}_{2}$ concentration $\left(\left[\mathrm{CO}_{2}\right]\right)$ and temperature, as well as rainfall patterns on crop development and growth, but also the effects of extreme events such as heat-waves, hail and flooding on crop productivity. Indirect pathways include changes in crop nutrition and occurrence of weeds, pests and diseases, environmental pollution (e.g. nitrate and pesticide leaching), changes in soil organic matter and irrigation needs.

Apart from increased temperature and concentration of $\mathrm{CO}_{2}$, also rise in tropospheric ozone concentration $\left(\left[\mathrm{O}_{3}\right]\right)$, which often appears to have the opposite effect of elevated $\mathrm{CO}_{2}$, damaging vegetation by reducing photosynthesis and other essential physiological functions is predicted (Collins et al., 2013). This results not only in decreased yields but also in inferior crop quality (Porter et al., 2014). Crop quality can be affected also by alteration in biochemical processes during grain development and maturation, as a consequence of the changed climate. Changes in temperature, $\left[\mathrm{CO}_{2}\right]$ and $\left[\mathrm{O}_{3}\right]$ will alter potential losses to many pests, weeds and diseases, with consequences on pest management in the future (Chakraborty and Newton, 2011). Important climate factors that are affected by climate change are listed in Table 1, which also reports their influence on crop production (crop yield, crop quality, crop diseases, weeds and pests), climate (incidence of extreme events), water (change in leaching of $\mathrm{N}$ and pesticides), and soil (soil organic carbon, SOC). It must be kept in mind that the climate factors act in combination, therefore influencing each other and their effects on crop production.

Table 1 Climate factors responsible for climate change (first column) and indication of their possible influence on crop production, climate, water loss and soil parameters (marked with $X$ ), as extracted from the IPCC AR5 WG I (Collins et al., 2013).

\begin{tabular}{lccccccc}
\hline \multirow{2}{*}{$\begin{array}{l}\text { Climate } \\
\text { factors }\end{array}$} & $\begin{array}{c}\text { Crop } \\
\text { yield }\end{array}$ & $\begin{array}{c}\text { Crop } \\
\text { quality }\end{array}$ & $\begin{array}{c}\text { Crop diseases, weeds } \\
\text { and pests }\end{array}$ & $\begin{array}{c}\text { Climate } \\
\text { of extreme } \\
\text { events }\end{array}$ & $\begin{array}{c}\text { Water loss } \\
\text { leaching }\end{array}$ & $\begin{array}{c}\text { Pesticide } \\
\text { leaching }\end{array}$ & $\begin{array}{c}\text { Soil organic } \\
\text { carbon }\end{array}$ \\
\hline $\mathrm{T}$ & $\mathrm{X}$ & $\mathrm{X}$ & $\mathrm{X}$ & $\mathrm{X}$ & $\mathrm{X}$ & $\mathrm{X}$ & $\mathrm{X}$ \\
{$\left[\mathrm{CO}_{2}\right]$} & $\mathrm{X}$ & $\mathrm{X}$ & $\mathrm{X}$ & $\mathrm{X}$ & & & $\mathrm{X}$ \\
{$\left[\mathrm{O}_{3}\right]$} & $\mathrm{X}$ & $\mathrm{X}$ & $\mathrm{X}$ & & & & \\
Rainfall & $\mathrm{X}$ & $\mathrm{X}$ & $\mathrm{X}$ & $\mathrm{X}$ & $\mathrm{X}$ & $\mathrm{X}$ & $\mathrm{X}$ \\
pattern & & & & & & & \\
\hline
\end{tabular}




\subsection{Options to include climate change effects on LCI of crop production}

This section discusses the possibilities to handle the modelling of the factors identified in Table 1 within the LCI phase. Different methodologies and sources of data can be used to address the different features of crop production in LCI, as detailed in the following sub-paragraphs. Particular emphasis is given to LCA studies performed under Danish conditions.

\subsubsection{Crop yield}

In LCAs of current crop production, crop yield data are usually retained either from single farms (Fedele et al., 2014) or groups of farms (Korsaeth et al., 2014; Roer et al., 2012) or from the FAOSTAT database (Nemecek et al., 2012). Crop yield has previously been shown to be the main driver for LCA results of crop production (Fedele et al., 2014; McDevitt and Milà i Canals, 2011; Middelaar et al., 2012; Nemecek et al., 2012; Roer et al., 2012). Therefore there is a need to base the assessment of future crop yield on the most reliable data, which should ideally originate from the system studied. However, this is not always an option, and LCA studies dealing with the quantification of the environmental impacts of future agricultural systems have normally been based on measurements of yields under past or current emission regimes, and based on this on estimations of future crop yields at predicted future emission levels. Examples of such approaches are the case of future poplar cultivation in Italy (González-García et al., 2012), global wheat demand starting from UK productions (Röder et al., 2014) or spring barley production under future Danish climate conditions (Dijkman, 2013). The tools usually used to predict the effect of climate change on crop productivity are crop growth simulation models, which are mainly based on single factor treatment, i.e. taking into consideration only elevated $\mathrm{CO}_{2}$ or elevated temperature (White et al., 2011). The effects of multi-factor treatment on crop yield have been included at experimental level, e.g. for oilseed rape (Clausen et al., 2011; Frenck et al., 2013, 2011) and spring barley (Alemayehu et al., 2013; Clausen et al., 2011). Studies of single-factors are more numerous than multi-factor, with the consequence that simulation studies, predicting the primary production of the future, build on the response to single-factor studies, but considerable uncertainty is embedded in the predictions. Even the projections of the future climate effects included in the last IPCC assessment report rely on modelling studies based predominantly on single-factor treatments.

The only study retrieved from literature addressing the effects of climate change on future crop production, namely spring barley production in Denmark under future circumstances (Dijkman, 2013) uses the data provided by Doltra et al. (2012), who used the dynamic FASSET crop model (Berntsen et al. 2003). This model was calibrated and tested for use in the environmental conditions of Denmark, and simulates crop growth and yield as affected by temperature, solar radiation, water and $\mathrm{N}$ availability and $\left[\mathrm{CO}_{2}\right]$.

\subsubsection{Crop quality}

Crop quality can be embedded in LCA with a proper selection of functional unit, e.g. choosing the nutritional value in terms of $\mathrm{kg}$ of protein as performed for wheat, barley and oat (Roer et al., 2012). Effects of climate on quality of crops have mainly been studied as change in $\mathrm{N}$ concentration, a proxy for protein concentration (Porter et al., 2014). Studies mainly reported the effects of single-factors $\left(\mathrm{T},\left[\mathrm{CO}_{2}\right]\right.$ or $\left[\mathrm{O}_{3}\right]$ ) on protein content. A study in barley on the combined influence of elevated soil temperature and reduced precipitation reported no change in protein concentration, but in the protein composition (Högy et al., 2013).

\subsubsection{Crop diseases, weeds and insects}

The effects of diseases, weeds and insects on crops are accounted for in current LCA considering the use of pesticide input as reported in the National statistics (Hamelin et al., 2012; Roer et al., 2012) or according to farm-specific practices (Fedele et al., 2014). Different approaches can be found in literature to describe the processes from pesticide spraying to emissions in soil, water and air, according to the definition of the 
boundaries between ecosphere and technosphere for agricultural field and its soil. The boundaries can be set to belong to the ecosphere as in Ecoinvent (Frischknecht et al., 2007), or the technosphere, as in PestLCI 2.0 (Dijkman et al., 2012) or in-between, according to the framework suggested by van Zelm et al. (2014). A changing climate will affect crop diseases, weeds and insects and therefore the pesticide use for control. A warmer climate is likely to lead to increased pest and disease pressure, as well as changes in efficacy of some of the herbicides, therefore calling for new and more resistant crops to be cultivated at the expense of existing crops (Olesen and Bindi, 2002). Other potential effects of a changed climate are shifts in sowing and planting dates and change in crop development times (Olesen et al., 2012) with consequences for the timing of pesticide applications. Since pest development and consequently pesticide application is part of the "known unknowns" connected with climate change, two approaches can be identified, i.e. either we consider current practice in areas currently having a climate similar to the climate expected for the region under study (Henriksen et al., 2012) or we consider the same type of pesticide used today with adjusted treatment index (Juroszek and von Tiedemann, 2011).

\subsubsection{Effects of extreme events}

The effects of different climatic conditions are usually addressed in crop LCA through sensitivity analysis, e.g. on spring rainfall index (Fedele et al., 2014) or type of climate (Dijkman, 2013; Korsaeth et al., 2014). More difficult to quantify is the impact of very extreme events on cropping systems, since by definition these occur very rarely and models cannot be adequately calibrated and tested (Porter et al., 2014). Experimental studies have reported effects of heat-waves on primary production supporting the projected decreases in grain yield (Ingvordsen, 2014). To our knowledge, no LCA study has previously included the effects of extreme events. The absence of such studies limits the assessment of the effects of adaptation solutions (Challinor et al., 2014), since more extreme events are expected to be a condition for crop cultivation in the future (IPCC, 2013).

\subsection{5 $\mathrm{N}$ and pesticide leaching}

For $\mathrm{N}$ leaching, dependent on the country of crop production, different models can be used, as reported in the World Food LCA Database (Nemecek et al., 2014), Agri-footprint Database (Blonk Agri-footprint BV, 2014) and Agribalyse (Colomb et al., 2014). The effects of projected changes in climate and $\left[\mathrm{CO}_{2}\right]$ on $\mathrm{N}$ leaching of arable land can be investigated with dynamic simulation models, e.g. Jensen and Veihe (2009). In the case of Dijkman (2013) nitrate leaching to water was based on interpolation of N leaching results from Doltra et al. (2012), showing that as a consequence of the predicted change in precipitation patterns, leaching will by 2050 increase $2 \%$ and $50 \%$ for sandy and sandy loam soils, respectively. For pesticide leaching no drastic increase of strongly adsorbing herbicides, fungicides, and insecticides is to be expected under Danish conditions, despite general increase in use of pesticides, but for low-dose and ordinary herbicides an increased leaching is foreseen (Henriksen et al., 2012).

\subsubsection{Soil organic carbon}

An approach to include soil carbon changes in LCA, and the consequent release of $\mathrm{CO}_{2}$ into the atmosphere, has been suggested by Petersen et al. (2013) based on the soil C model C-TOOL (Petersen, 2010). Examples of application of this tool in crop production under current climate conditions are detailed, e.g. in Hamelin et al. (2012) and Knudsen et al. (2014). Soil C balance is influenced by local factors, e.g. type of soil, and management practices, such as fertilizer application method and crop residue management, as well as by changes in climatic conditions, especially temperature and moisture (Berntsen et al., 2006). An updated list of soil carbon models is provided in the review by Stockmann et al. (2013). 


\subsection{Recommended approach to develop LCA scenarios of future crop production in a changed climate} With regard to the different options listed in section 2.2 we suggest to prioritize the use of primary data from experiments mimicking future climate conditions, and to supplement these data with the outcomes of simulation models, where primary data are absent. Since the quality of data used in LCA is strictly related to the availability of primary data, the suggestion for LCA in the cereal and derived products sector is to use literature data for the background system and primary data for the foreground (Renzulli et al., 2015). Furthermore, whenever possible a statistical approach to data collection and evaluation should be used to check the representativeness of the data (Renzulli et al., 2015).

In order to take the alternative future conditions and uncertainties about the future into account, we recommend the following 3 -step procedure to develop scenario analysis of the future crop production (see Figure 1):

1. Define the baseline scenario at the LCI level for the selected crop and perform the LCIA including normalization and contribution analysis, in order to identify the focus points in terms of impact categories, unit processes and substances;

2. For the focus points, identify the main deviations from the baseline scenario using the best available data and knowledge with identification of alternative scenarios, according to the possible different values of the production parameters, as well as climate, water loss and soil parameters;

3. Compare the different scenarios including a quantification of the uncertainty at inventory level to identify the most relevant environmental issues of the future cultivation.

Once the environmental issues have been identified, it will be possible to prioritize the selection of relevant adaptation strategies to minimize the environmental impacts.

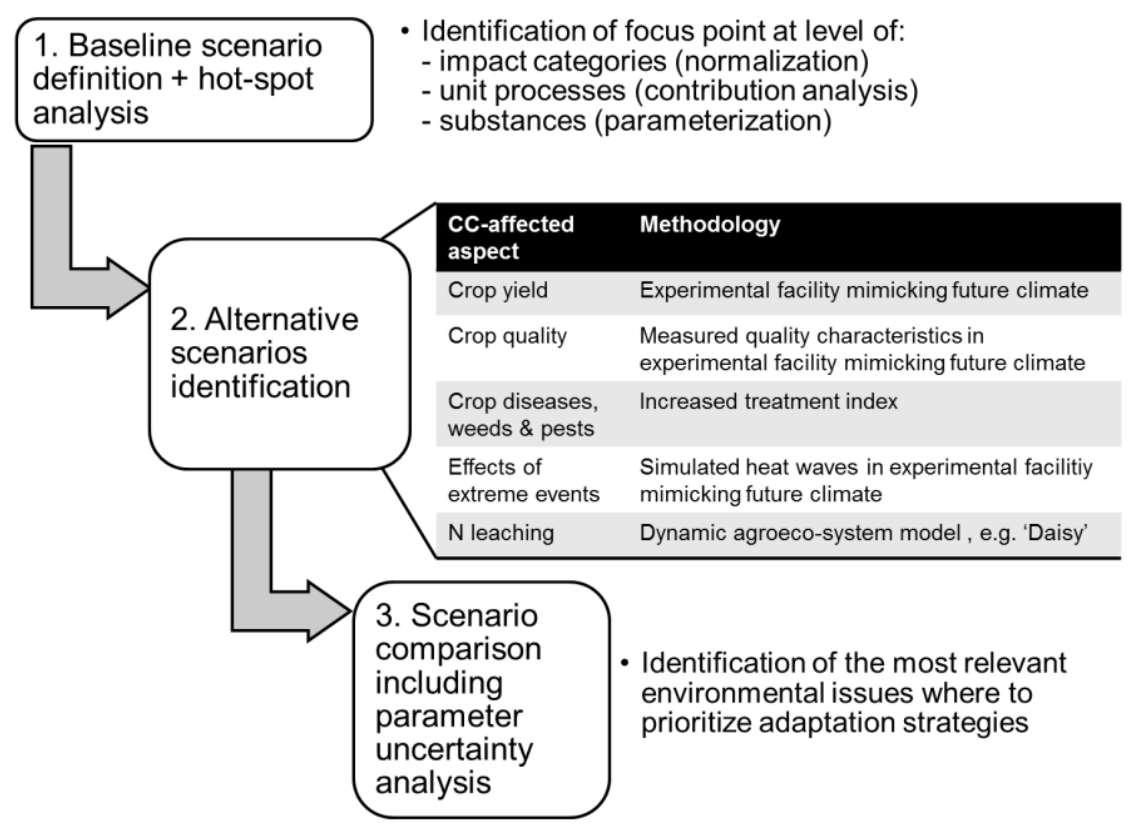

Figure 1 Graphical representation of the 3-step procedure for scenario analysis in the development of consistent LCI of future crop production considering climate change effects. In step 2 the table exemplifies, how we applied the guidelines in the case study presented below.

For the hotspot analysis in step 1 (Figure 1) we suggest to perform LCIA at midpoint including normalization, or alternatively to perform endpoint modelling in order to identify the relative importance of the different midpoint impact categories. When the most relevant impact categories have been identified by a 
contribution analysis on the baseline scenario, we can detect the process units and related substances mainly responsible for the impact, whose variations in a future climate need to be quantified. In order to streamline the following scenario analysis we suggest parameterizing the LCI. Parameterization at the LCI level has already proven to be beneficial in many sectors, e.g. for packaging (Niero et al., 2014a) and industrial systems (Cluzel et al., 2013).

In the identification of alternative future scenarios (step 2 in Figure 1) we recommend to quantify the main deviations from the baseline scenario favoring the use of primary data, as detailed in Figure 1 for the main climate change-affected parameters, i.e. crop yield, crop quality, effects of extreme events. It is most likely the case that more than one future scenario will be identified, since more options are possible for the same parameter under the same climate conditions, e.g. in the case of crop yield, different set of cultivars can be available.

LCIA results are usually reported in terms of single impact category values, but the use of data points can mislead the results. Therefore it is important to present LCIA results with intervals, which provide an indication of the uncertainty associated with different scenarios. For quantifying the uncertainty at LCI level due to model imprecision, input uncertainty and data variability, we used uncertainty analysis (step 3 in Figure 1). We focused on the influence of data variability and performed parameter uncertainty analysis using a 1000-run Monte Carlo analysis (Frischknecht et al., 2007) including probability distribution based on the method presented in Niero et al. (2014c), applicable when direct measurements on parameter variations are available. In the absence of measured data we suggest to derive the probability distribution according to the methodology implemented in the Ecoinvent database (Ciroth et al., 2013). We therefore calculated the geometric standard deviation based on data quality assessment on five data quality indicators: reliability, completeness, temporal correlation, geographical correlation, further technological correlation and one basic uncertainty factor which depends on the type of input flow and process. Parameter uncertainty analysis by the means of Monte Carlo simulation is a well-defined technique in the context of agricultural LCA, see e.g. (Basset-Mens et al., 2009; Bojacá et al., 2014; Fedele et al., 2014). However, we are aware that other methods for parameter uncertainty analysis can be applied (Lloyd and Ries, 2007), but the one recommended can be easily implemented without further data collection.

\subsection{Case study: spring barley cultivation in Denmark under future climate change}

High-quality field or experimental data are rarely available as primary data to LCA, but we produced data in the unique phytotron RERAF (Risø Environmental Risk Assessment Facility), where atmospheric composition and other environmental factors can be manipulated and combined, controlled and continuously monitored in order to have plant material screened under realistic future climate scenarios. RERAF consists of six identical chambers of $4.0 \mathrm{~m}$ (width) x 6.0 (length) $\mathrm{m} \times 3.1 \mathrm{~m}$ (height) equipped with individual control of light, temperature, humidity, $\left[\mathrm{CO}_{2}\right]$ and $\left[\mathrm{O}_{3}\right]$. This facility was used to perform experiments, analyzing both the production and quality of spring barley and oilseed rape in future climate scenarios (e.g. Alemayehu et al., 2013; Clausen et al., 2011; Frenck et al., 2013, 2011) under single- and multi-factor treatments.

According to IPCC AR5, we are currently approaching the worst-case scenario Representative Concentration Pathway 8.5 (RCP8.5), unless actions are taken collectively in the very near future. The RCP8.5 refers to the approximate total radiative forcing in year 2100 relative to 1750 (IPCC, 2014b). In the RCP8.5 scenario $\left[\mathrm{CO}_{2}\right]$ is projected to reach around $1,000 \mathrm{ppm}$ at the end of the $21^{\text {st }}$ century and global mean temperature will increase approximately $5^{\circ} \mathrm{C}$. The experimental conditions in RERAF reproduce approximately this scenario, considering $+5^{\circ} \mathrm{C}$ temperature increase and $700 \mathrm{ppm}\left[\mathrm{CO}_{2}\right]$. Different sets of experiments have been performed both combining climate factors and extreme events, as described in Ingvordsen (2014) and Ingvordsen et al. (2015a). Crop yields in kg dry matter (DM) grain, and crop quality, in \% crude protein 
$(\mathrm{CP})$, were measured under two-factor treatment of $\mathrm{CO}_{2}$ and temperature, and crop yields were also measured under extreme heat-wave conditions superimposed to elevated temperature and $\left[\mathrm{CO}_{2}\right]$. Furthermore, crop yields were calculated at cultivar level, as reported in Ingvordsen (2014) and Ingvordsen et al.(2015a). For the LCA we considered two different sets of cultivars: one set including 13 cultivars for which experiments have been performed under current ambient conditions (400 ppm $\left[\mathrm{CO}_{2}\right], 19 / 12{ }^{\circ} \mathrm{C}$ day/night), two-factor treatment (700 ppm $\left[\mathrm{CO}_{2}\right], 24 / 17{ }^{\circ} \mathrm{C}$ day/night) and a long heat-wave $\left(700 \mathrm{ppm}\left[\mathrm{CO}_{2}\right]\right.$, $33 / 28^{\circ} \mathrm{C}$ day/night for 10 days), and a further set including only the five highest yielding cultivars under the two-factor treatment. Experiments including the effect of increased $\left[\mathrm{O}_{3}\right]$ have also been performed, but $\mathrm{O}_{3}$ was not combined with elevated $\mathrm{CO}_{2}$ and temperature. Crop production under Scandinavian conditions is mainly rain-fed under current climatic conditions. The effect of irrigation was not investigated directly, as all treatments were given the same amount of water as the ambient. Therefore the treatments with elevated temperature were indirectly drought-stressed. The response to diseases, weeds and insects was partly simulated with the climate phytotron, and the experiments in RERAF showed that mildew on barley increased significantly in a changed climate (Mikkelsen et al., 2014).

With regard to the list of climatic factors reported in Table 1 we focused on the effect of increased $\mathrm{T}$ and $\left[\mathrm{CO}_{2}\right]$ on crop yield and crop quality, as well as their influence on extreme heat-wave event, crop diseases, weeds and pests and $\mathrm{N}$ leaching, even though primary data were only partially available for the last two factors. The influence of pesticide leaching was excluded, since a study conducted under Danish condition revealed its contribution to be negligible in the case of sandy soil (Henriksen et al., 2012). Also the effect of changed temperature and moisture on soil organic carbon dynamics was not included, since RERAF was not equipped with instruments to measure the change of these factors.

\section{Results}

Based on the approach described in section 2.3, we firstly defined a baseline scenario describing Danish spring barley cultivation under current climate conditions from a cradle to farm gate perspective. The definition of the current production included the quantification of inputs and outputs for the main agricultural operations, i.e. soil preparation operations (ploughing, harrowing, fertilizer application), sowing, external agents (weed-, disease-, and insect- animal control), harvesting, drying and storage and the quantification of field emissions into air (dinitrogen monoxide, nitrogen oxides, ammonia, carbon dioxide) and into water (nitrate, phosphorus, copper and zinc). The details of the LCI inputs and outputs are reported in Niero et al. (2015b). The normalized LCIA results at midpoint level for a reference flow of $1 \mathrm{~kg}$ of DM barley were obtained with the ReCiPe LCIA methodology v1.10 (Goedkoop et al., 2009), which has recently been used to assess spring barley cultivation (Dijkman, 2013; Fedele et al., 2014; Roer et al., 2012). The ReCiPe method considers three different cultural perspectives (hierarchical, egalitarian and individualist), which reflect different ways of modelling the cause-effect pathway from interventions to damage, according to preference choices, e.g. time horizon, and contextual values, e.g. technological advancements which will allow degrees of adaptation and damage avoidance (De Schryver et al., 2011). The choice of the cultural perspective is a source of scenario uncertainty, which can be overcome by performing the LCIA with all three perspectives as a sensitivity check, see e.g. Treyer et al., (2014) for the case of electricity production. The normalized midpoint results are reported in Figures 2, 3, and 4 for the hierarchical, egalitarian and individualist perspectives, respectively. 


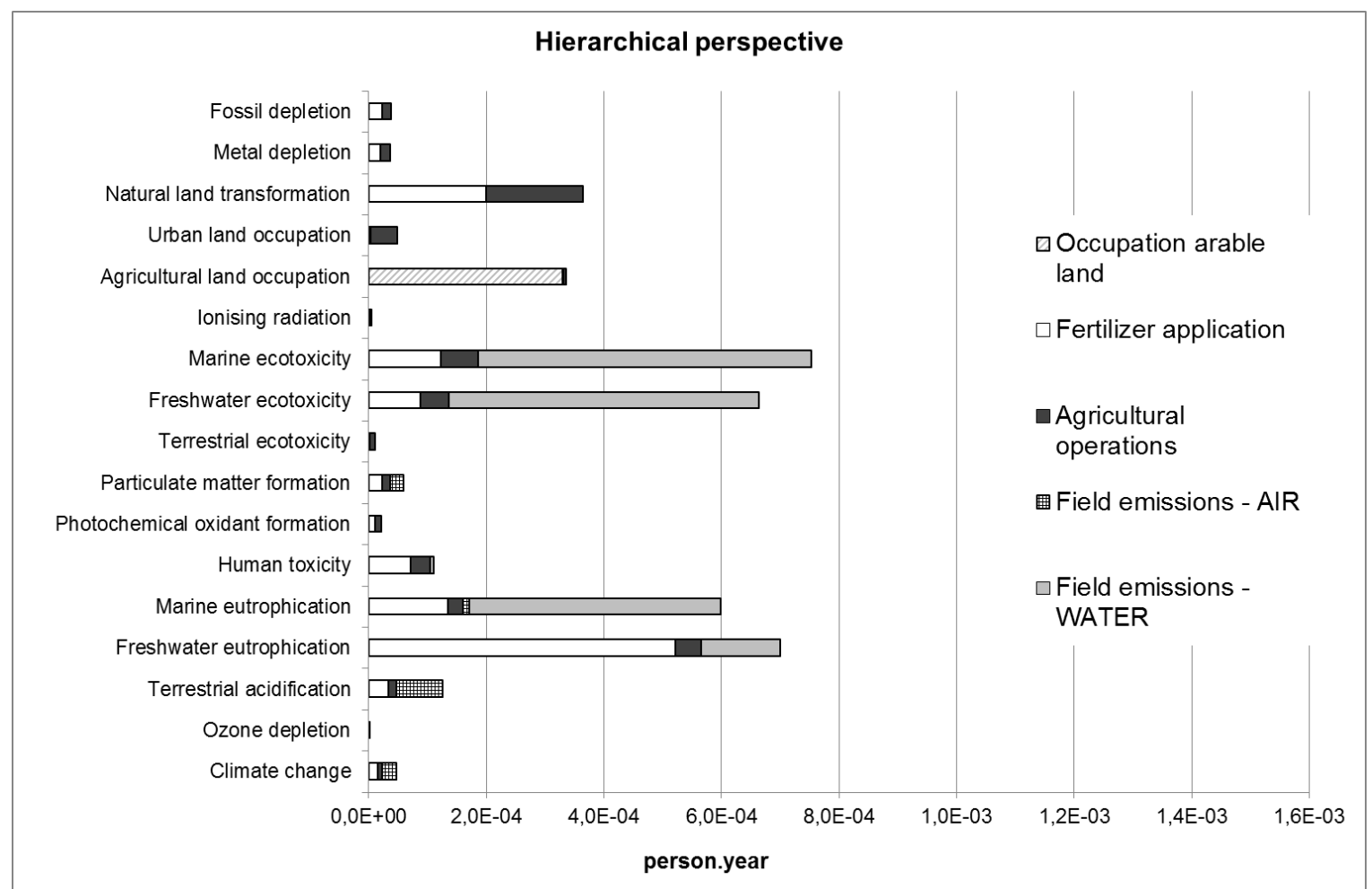

Figure 2 Normalized midpoint results with hierarchical cultural perspective for a reference flow of $1 \mathrm{~kg}$ barley produced in the baseline scenario of current spring barley cultivation in Denmark.

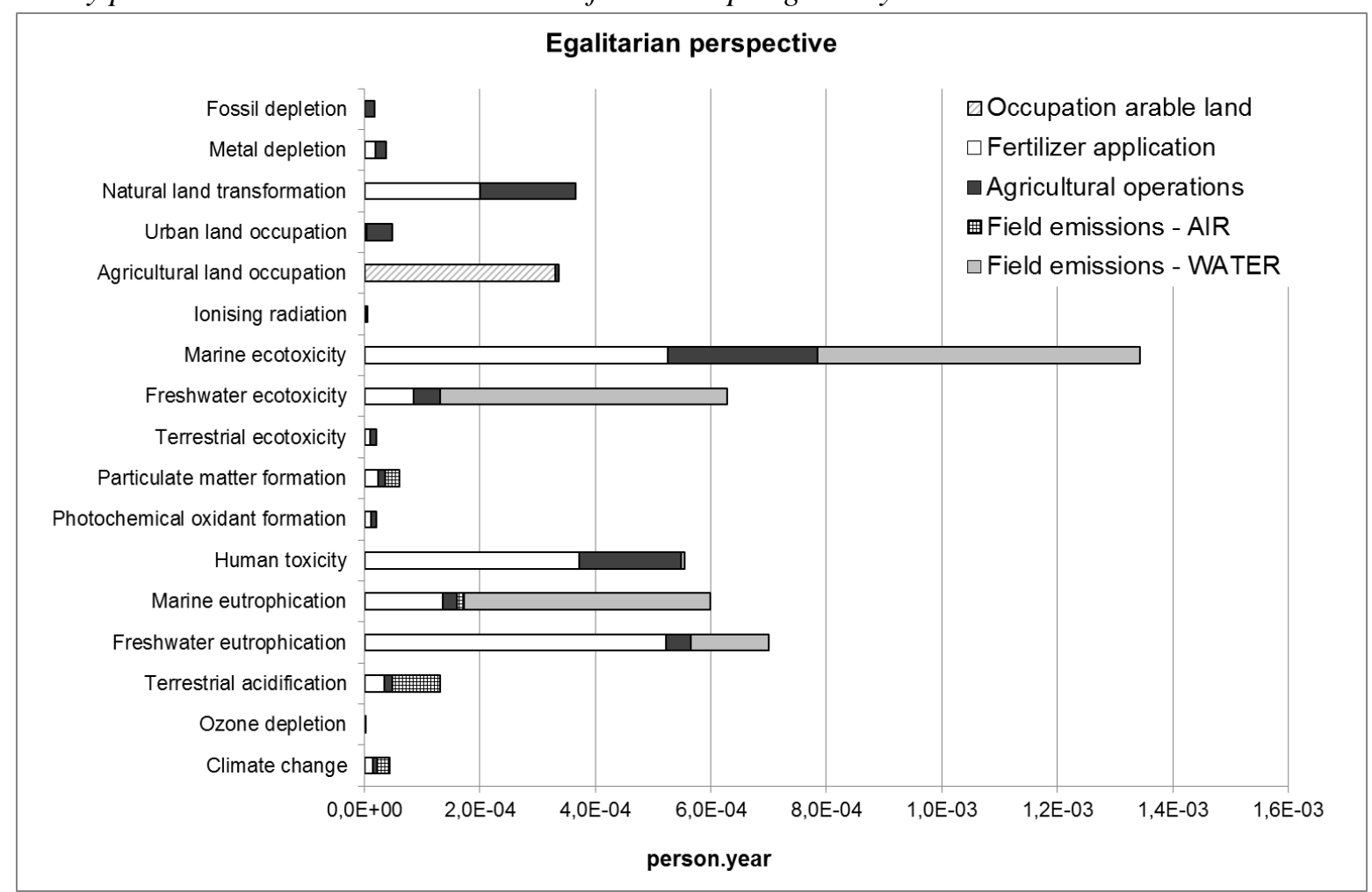

Figure 3 Normalized midpoint results with egalitarian cultural perspective for a reference flow of $1 \mathrm{~kg}$ barley produced in the baseline scenario of current spring barley cultivation in Denmark. 


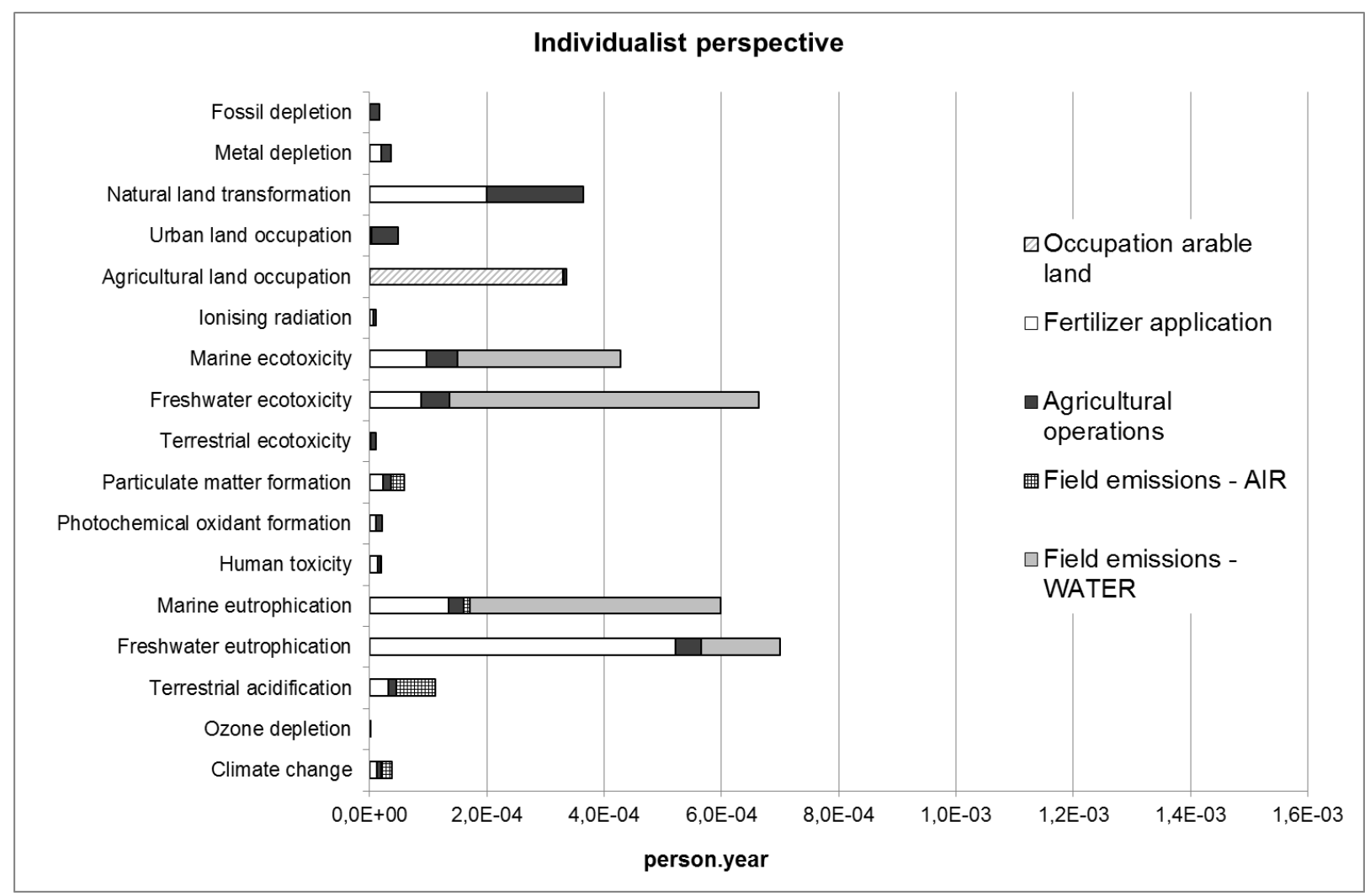

Figure 4 Normalized midpoint results with individualist cultural perspective for a reference flow of $1 \mathrm{~kg}$ barley produced in the baseline scenario of current spring barley cultivation in Denmark.

From the comparison among the normalized midpoint results for the three cultural perspectives, the five impact categories resulting as the most relevant across the three perspectives are: freshwater eutrophication (FE), marine eutrophication (ME), freshwater ecotoxicity (FET), marine ecotoxicity (MET), and natural land transformation (NLT). Therefore, we focus our analysis on the identification of the parameters influencing these impact categories. We further include the climate change (CC) impact category since the quantification of the effects of climate change is the driver of the study.

From the contribution analysis on the normalized LCIA (hierarchical perspective) the hot-spots at unit process level are field emissions to water (for FE, ME, MET, FET), fertilizer application (for FE, ME, MET, FET, NLT, CC) and field emissions to air (for CC). For each unit process we set a cut-off of $5 \%$ at the emission level and identified the most contributing substances with a distinction between user-defined parameters, e.g. P and $\mathrm{N}$ component of pig and cattle manure (fertP_cat, fertN_cat, fertP_pig, fertP_cat), P component of mineral fertilizer (fertP_min), nitrate leaching (Nleach) and secondary parameters, which are not defined by the practitioner, but included in the background data, e.g. emissions of $\mathrm{Ni}$ ion in electricity used in fertilizer production and transformation of land in fertilizer production, as reported in Table 2. In terms of unit processes contribution, our LCIA results are in accordance with previous LCA studies on spring barley under Danish (Dijkman, 2013) and Norwegian (Roer et al., 2012) conditions, which identify field emissions and fertilizer application as the main contributors to the impact for CC, ME, FE, FET, MET. The main reasons behind the differences in the scores of the impact categories are discussed in Niero et al. (2015b). 
Table 2 Results of the hot-spot analysis for the impact categories freshwater eutrophication, marine eutrophication, freshwater ecotoxicity, marine ecotoxicity, natural land transformation, and climate change, reporting main contributing unit processes and individual substances (expressed as \% on the overall impact category, with indication of the user-defined parameters and secondary parameters in the model).

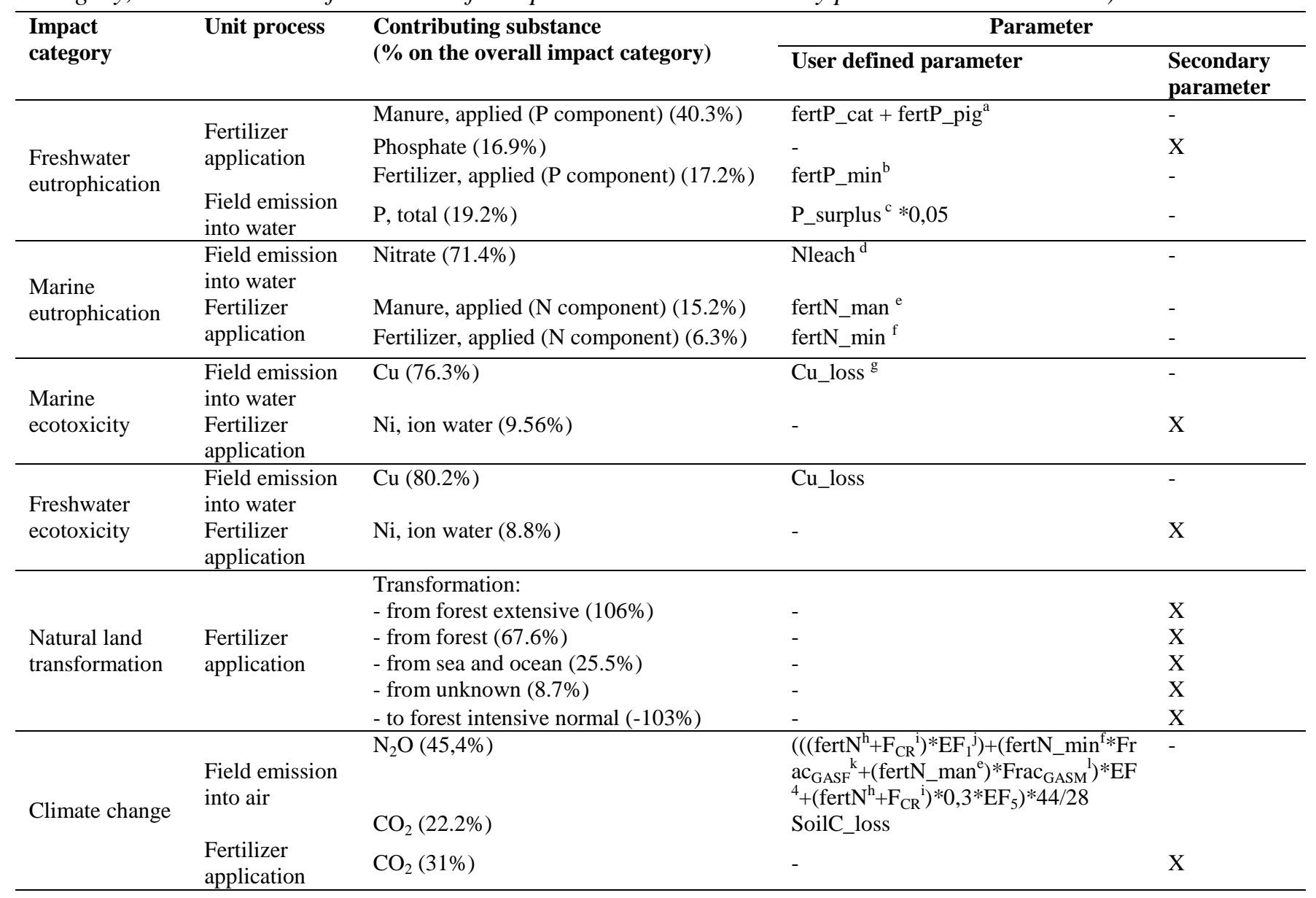

${ }^{\mathrm{a}}$ fertP_cat + fertP_pig $=\mathrm{P}$ component of cattle manure $+\mathrm{P}$ component of pig manure, $[\mathrm{kg} \mathrm{P}]$

${ }^{\mathrm{b}}$ fertP_min $=\mathrm{P}$ component of mineral fertilizer, $[\mathrm{kg} \mathrm{P}]$

${ }^{\mathrm{c}} \mathrm{P}$-surplus $=\mathrm{P}$ surplus application given by fertP $(=$ fertP_cat + fertP_pig + fertP_min $)-$ uptake from primary yield $(=3 *$ yield*DM/1000), [kg P]

${ }^{\mathrm{d}}$ Nleach $=$ nitrate leaching, $\left.\mathrm{kg} \mathrm{NO}_{3}{ }^{-}\right]$

${ }^{\mathrm{e}}$ fertN_cat + fertN_pig $=\mathrm{N}$ component of cattle manure $+\mathrm{N}$ component of pig manure, $[\mathrm{kg} \mathrm{N}]$

${ }^{\mathrm{f}}$ fertN_min $=\mathrm{N}$ component of mineral fertilizer, $[\mathrm{kg} \mathrm{N}]$

${ }^{\mathrm{g}} \mathrm{Cu} \_$loss $=\mathrm{Cu}$ amount in slurry $-\mathrm{Cu}$ uptake from primary yield $(=3 *$ yield*DM/1000000), $[\mathrm{kg} \mathrm{Cu}]$

${ }^{\mathrm{h}}$ fertN $=$ total $\mathrm{N}$ component from mineral and organic fertilizers $=$ fertN_cat + fertN_pig + fertN_min, [kg N]

${ }^{\mathrm{i}} \mathrm{F}_{\mathrm{CR}}=\mathrm{N}$ component in crop residue, $[\mathrm{kg} \mathrm{N}]$

${ }^{\mathrm{j}} \mathrm{EF}_{1}, \mathrm{EF}_{4}, \mathrm{EF}_{5}=$ default emission factors to estimate direct $\mathrm{N} 2 \mathrm{O}$ emissions from managed soils (IPCC, 2006), [kg N-N $\mathrm{k}_{2} / \mathrm{kgN}$ ]

${ }^{\mathrm{k}}$ Frac $_{\mathrm{GASF}}=$ fraction of synthetic fertilizer $\mathrm{N}$ that volatilizes as $\mathrm{NH}_{3}$ and $\mathrm{NO}_{\mathrm{X}}(\mathrm{IPCC}, 2006)$, [kg N volatilized/kg N applied]

${ }^{1} \mathrm{Frac}_{\mathrm{GASM}}=$ fraction of applied organic $\mathrm{N}$ fertilizer materials that volatilizes as $\mathrm{NH}_{3}$ and $\mathrm{NO}_{\mathrm{X}}(\mathrm{IPCC}, 2006),[\mathrm{kg} \mathrm{N}$

volatilized/kg N applied]

${ }^{\mathrm{m}}$ SoilC_loss $=$ loss of soil $\mathrm{C},[\mathrm{kg} \mathrm{C}]$ 
In step 2 of our approach we identified the main future deviations from the current production for the userdefined parameters, under the assumption of constant fertilizer application rate in terms of $\mathrm{kg} \mathrm{N} / \mathrm{ha}$, as done by Dijkman (2013). Field emissions were calculated per ha of cultivated area and were rescaled in terms of functional unit (i.e. $1 \mathrm{~kg}$ DM grain) dividing by the crop yield $(\mathrm{kg} / \mathrm{ha})$.

The combination of the changes in crop yield, $\mathrm{N}$ leaching and treatment index led to the definition of five alternative future scenarios (S1-S5), as reported in Table 3.

For quantifying the deviation of crop yield from current values, we considered the outcomes from RERAF experiments, which indicate a decrease of $26.2 \%$ (S1) and $33.5 \%$ (S3) from current crop yield for the combined treatment and extreme heatwave event over 13 cultivars, respectively, and a reduction of $2.1 \%$ (S2) and 28.6\% (S4) for the combined treatment and extreme heat-wave event, over the 5 highest yielding cultivars, respectively(Niero et al., 2015). In order to test the significance of use of primary data against the practice of using secondary data for crop yield prediction, we considered the results obtained by Doltra et al. (2012), which indicate a yield decrease of $34.8 \%$ (S5) for spring barley under similar climate conditions (639 ppm $\left[\mathrm{CO}_{2}\right]$ and A1B IPCC 2007 scenario, corresponding to average increase of $2.8^{\circ} \mathrm{C}$ ) and compared them to the outcomes of scenarios S1 and S2, which refer to combined treatment.

With regard to nitrate leaching under the assumption of constant $\mathrm{N}$ fertilizer application, we used literature data valid for Danish conditions and thus considered an increase of nitrate leaching of 24\% (Jensen and Veihe, 2009).

Concerning pesticide application we considered an increase of the treatment index of $25 \%$, based on the prediction of Juroszek and von Tiedemann (2011), under the assumption that in the future, the same herbicide, insecticide and fungicide types will be used as today. Pesticide emissions into the environment were then modelled using the PestLCI 2.0 model (Dijkman et al., 2012).

Table 3 List of the scenarios considered, i.e. the baseline $(B)$ and the identified alternative future scenarios (S1-S5) according to the estimated deviations from current production for N leaching and crop yield, under the assumption of an increase of $25 \%$ in pest treatment index. The probability distribution for crop yield and $N$ leaching values are also included, as well as quantification of the variation in terms of standard deviation.

\begin{tabular}{|c|c|c|c|c|}
\hline $\begin{array}{l}\text { Scenario } \\
\text { identification }\end{array}$ & $\begin{array}{c}\text { Nitrate } \\
\text { leaching } \\
{\left[\mathrm{kg} \mathrm{NO}_{3}^{-} / \mathrm{ha}\right]}\end{array}$ & $\begin{array}{c}\text { Type of distribution and } \\
\text { variation }\end{array}$ & $\begin{array}{c}\text { Crop } \\
\text { yield } \\
{[\mathrm{kg} / \mathrm{ha}]}\end{array}$ & $\begin{array}{c}\text { Type of distribution and } \\
\text { variation }\end{array}$ \\
\hline Baseline (B) & 126 & $\begin{array}{l}\text { Uniform; } \\
\text { [120-142] }\end{array}$ & 5700 & $\begin{array}{l}\text { Normal; } \\
2 \sigma=1,26\end{array}$ \\
\hline S1 & 157 & $\begin{array}{l}\text { Lognormal; } \\
\sigma_{\mathrm{g}}{ }^{2}=1,727\end{array}$ & 4207 & $\begin{array}{l}\text { Normal } \\
2 \sigma=26,6\end{array}$ \\
\hline $\mathrm{S} 2$ & 157 & $\begin{array}{l}\text { Lognormal; } \\
\sigma_{\mathrm{g}}^{2}=1,727\end{array}$ & 5580 & $\begin{array}{l}\text { Normal } \\
2 \sigma=12,2\end{array}$ \\
\hline S3 & 157 & $\begin{array}{l}\text { Lognormal; } \\
\sigma_{\mathrm{g}}^{2}=1,727\end{array}$ & 3791 & $\begin{array}{l}\text { Normal } \\
2 \sigma=23,4\end{array}$ \\
\hline S4 & 157 & $\begin{array}{l}\text { Lognormal; } \\
\sigma_{\mathrm{g}}^{2}=1,727\end{array}$ & 4070 & $\begin{array}{c}\text { Normal } \\
2 \sigma=23,2\end{array}$ \\
\hline S5 & 157 & $\begin{array}{l}\text { Lognormal; } \\
\sigma_{\mathrm{g}}^{2}=1,727 \\
\end{array}$ & 3716 & $\begin{array}{c}\text { Uniform } \\
{[3420-3848]}\end{array}$ \\
\hline
\end{tabular}

Table 3 also includes the probability distribution used to perform Monte Carlo analysis for crop yield, based on the data measured from RERAF (for scenarios S1-S4) and data retrieved from Doltra et al.(2012) for S5. For the baseline scenario input data were retrieved for a period of five years to account for the temporal variability, e.g. for current crop yield data, current amount of $\mathrm{N}$ fertilizer applied, and content of $\mathrm{N}$ and $\mathrm{P}$ in animal slurry(Niero et al., 2015). For all these input data we assumed normal distribution and calculated the 
arithmetic mean and standard deviation, as reported in Table 3 for crop yield and Table 4 for all the other parameters. Concerning the variation of the amount of $\mathrm{N}$ and $\mathrm{P}$ in future mineral and organic fertilizer we used the same value as today and calculated the variance according to the methodology implemented in the Ecoinvent database. This methodology consists in giving a score to the data quality according to their characteristics in terms of reliability, completeness, temporal correlation, geographical correlation, further technological correlation in the form of a Pedigree matrix (Ciroth et al., 2013). The inputs to the calculation as well as the value of the geometric standard deviation are reported in Table 4. We also included the uncertainty range in the IPCC emissions factors for calculation of direct and indirect $\mathrm{N}_{2} \mathrm{O}$ emissions $\left(\mathrm{EF}_{1}\right.$, $\left.\mathrm{EF}_{4}, \mathrm{EF}_{5}, \mathrm{Frac}_{\mathrm{GASF}}\right)(\mathrm{IPCC}, 2006)$.

Table 4 Estimated means, probability distribution and variation for the user-defined parameters for baseline $(B)$ and future alternative scenarios (S1-S5). The parameters in the first column are described in the notes to Table 2.

\begin{tabular}{|c|c|c|c|c|c|c|}
\hline Scenario & & Bas & line (B) & & Futu & S1-S5) \\
\hline Parameter & $\begin{array}{l}\text { Estimate } \\
\mathrm{d} \text { mean }\end{array}$ & $\begin{array}{c}\text { Distributio } \\
\mathrm{n}\end{array}$ & Variation & $\begin{array}{l}\text { Estimate } \\
\text { d mean }\end{array}$ & $\begin{array}{c}\text { Distributio } \\
n\end{array}$ & Variation \\
\hline fertN_cat & 43,91 & Normal & $2 \sigma=5,42$ & 43,91 & Lognormal & $\begin{array}{c}\text { Pedigree matrix: } \\
(4,4,5,4,5) \sigma_{\mathrm{g}}^{2}=1,727\end{array}$ \\
\hline fertN_pig & 34,06 & Normal & $2 \sigma=2,68$ & 34,06 & Lognormal & $\begin{array}{l}\text { Pedigree matrix: } \\
(4,4,5,4,5) \sigma_{\mathrm{g}}^{2}=1,727\end{array}$ \\
\hline fertN & 113 & Normal & $2 \sigma=7,34$ & 113 & Lognormal & $\begin{array}{c}\text { Pedigree matrix: } \\
(4,4,5,4,5) \sigma_{\mathrm{g}}^{2}=1,727\end{array}$ \\
\hline fertP_cat & 7,34 & Normal & $2 \sigma=1,26$ & 7,34 & Lognormal & $\begin{array}{l}\text { Pedigree matrix: } \\
(4,4,5,4,5) \sigma_{\mathrm{g}}^{2}=1,727\end{array}$ \\
\hline fertP_pig & 8,34 & Normal & $2 \sigma=1,46$ & 8,34 & Lognormal & $\begin{array}{c}\text { Pedigree matrix: } \\
(4,4,5,4,5) \sigma_{\mathrm{g}}^{2}=1,727\end{array}$ \\
\hline fert $P$ & 22 & Normal & $2 \sigma=0,8$ & 22 & Lognormal & $\begin{array}{l}\text { Pedigree matrix: } \\
(4,4,5,4,5) \sigma_{\mathrm{g}}^{2}=1,727\end{array}$ \\
\hline SoilC_loss & 792 & Lognormal & $\begin{array}{l}\text { Pedigree matrix:(2,3,1,1,2) } \\
\qquad \sigma_{\mathrm{g}}{ }^{2}=1,283\end{array}$ & 792 & Lognormal & $\begin{array}{l}\text { Pedigree matrix: } \\
(4,4,5,4,5) \sigma_{\mathrm{g}}^{2}=1,711\end{array}$ \\
\hline $\mathrm{EF}_{1}$ & 0,01 & Uniform & {$[0,003-0,03]$} & 0,01 & Uniform & {$[0,003-0,03]$} \\
\hline $\mathrm{EF}_{4}$ & 0,01 & Uniform & {$[0,002-0,05]$} & 0,01 & Uniform & {$[0,002-0,05]$} \\
\hline $\mathrm{EF}_{5}$ & 0,0075 & Uniform & {$[0,0005-0,025]$} & 0,0075 & Uniform & {$[0,0005-0,025]$} \\
\hline $\mathrm{Frac}_{\mathrm{GASF}}$ & 0,1 & Uniform & {$[0,03-0,3]$} & 0,1 & Uniform & {$[0,03-0,3]$} \\
\hline $\mathrm{Frac}_{\mathrm{GASM}}$ & 0,2 & Uniform & {$[0,05-0,5]$} & 0,2 & Uniform & {$[0,05-0,5]$} \\
\hline
\end{tabular}

Based on the probability distribution of the input data (Table 3 and Table 4) the Monte Carlo simulation provided the coefficient of variation, i.e. standard deviation divided by the mean, of each environmental impact category. This value was used as a measure of the uncertainty of the impact category (Bojacá et al., 2014), reported in Table 5 and the distribution and confidence intervals of the results of each impact category in Fig. 5. 
Table 5 Coefficient of variation of the characterized impact category scores for the impact categories identified through the hot-spot analysis for the baseline $(B)$ and alternative future scenarios (S1-S5).

\begin{tabular}{llcccccc}
\hline Impact categories & Unit of measurement & $\mathrm{B}$ & $\mathrm{S} 1$ & $\mathrm{~S} 2$ & $\mathrm{~S} 3$ & $\mathrm{~S} 4$ & $\mathrm{~S} 5$ \\
\hline Climate change & $\mathrm{kg} \mathrm{CO}_{2} \mathrm{eq}$ & $16 \%$ & $34,4 \%$ & $34,1 \%$ & $34,8 \%$ & $34,4 \%$ & $34,7 \%$ \\
Natural land transformation & $\mathrm{m}^{2}$ & $73,7 \%$ & $88,1 \%$ & $81,4 \%$ & $86,8 \%$ & $83,6 \%$ & $86,3 \%$ \\
Freshwater eutrophication & $\mathrm{kg} \mathrm{P} \mathrm{eq}$ & $10,7 \%$ & $42 \%$ & $46 \%$ & $40,3 \%$ & $40,7 \%$ & $39,9 \%$ \\
Marine eutrophication & $\mathrm{kg} \mathrm{N} \mathrm{eq}$ & $3,72 \%$ & $21,9 \%$ & $22 \%$ & $22,2 \%$ & $21,3 \%$ & $22,1 \%$ \\
Freshwater ecotoxicity & $\mathrm{kg} \mathrm{1,4-DB}$ eq & $7,52 \%$ & $12,4 \%$ & $13,8 \%$ & $12,4 \%$ & $19,9 \%$ & $19,5 \%$ \\
Marine ecotoxicity & $\mathrm{kg} \mathrm{1,4-DB} \mathrm{eq}$ & $8,47 \%$ & $14,5 \%$ & $15,9 \%$ & $14,5 \%$ & $21,9 \%$ & $22,1 \%$ \\
\hline
\end{tabular}
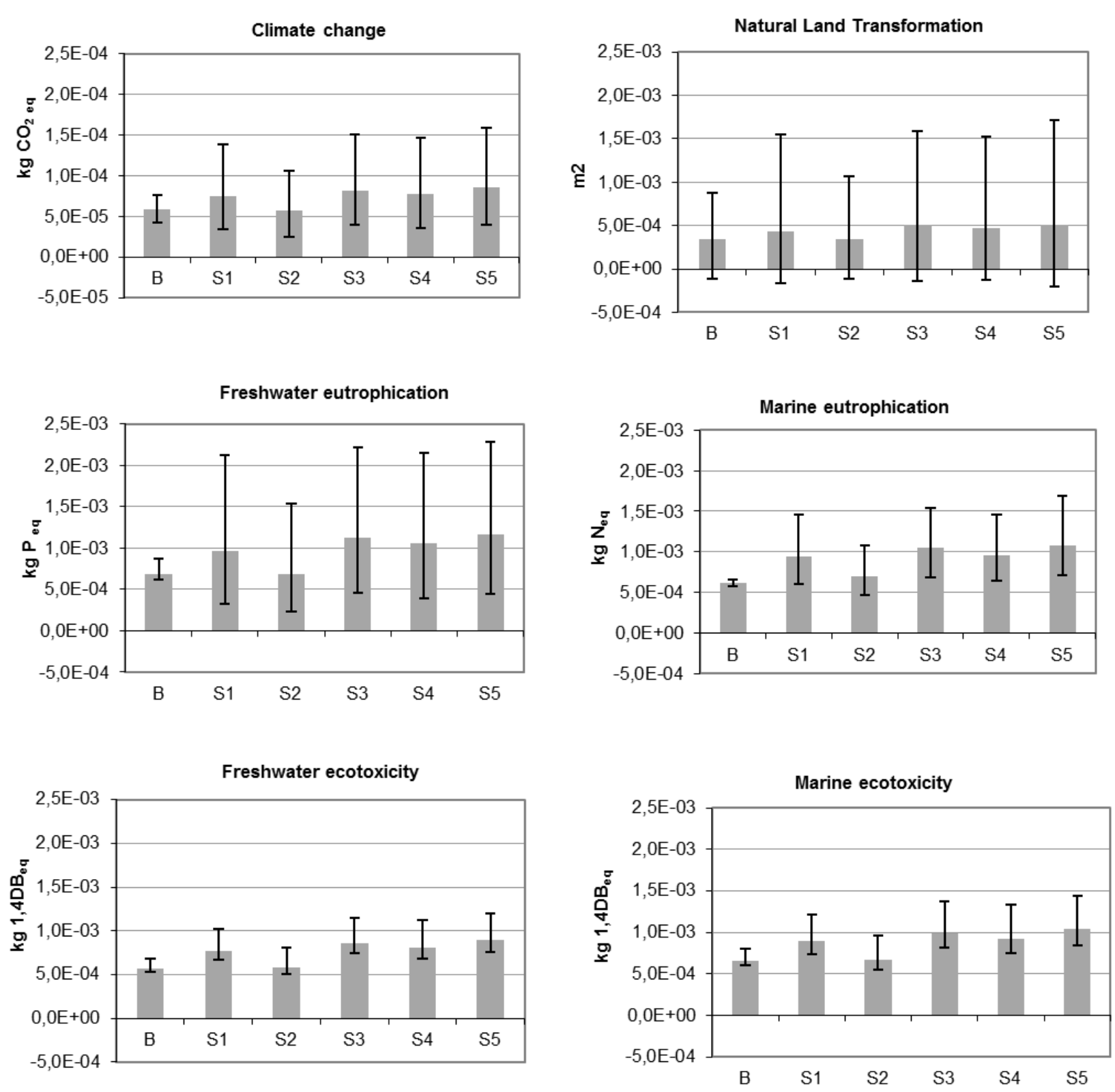

Figure 5. Characterized midpoint results obtained with ReCiPe (hierarchical) with $95 \%$ confidence interval (error bars) calculated through Monte Carlo simulation for the baseline (B) and future alternative scenario (S1-S5). The error bars indicate that in 95\% of the cases the characterized LCIA would fall within the range. Please note that the scale for climate change is one of order of magnitude smaller than the other impact categories. 
$\mathrm{ME}$ and $\mathrm{FE}$ values display the largest change of the coefficient of variation from the baseline to future scenarios (Table 5) as also visible from Figure 5. As the main contribution to $\mathrm{FE}$ is the emission of the $\mathrm{P}$ component from manure and mineral fertilizer, there is a direct link between the statistical distribution of this emission (Table 4) and the uncertainty associated with the final results. For the alternative future scenarios (S1-S5) we neglected the indirect effect of climate change on feed composition and quality of manure, therefore the uncertainty associated with the $\mathrm{P}$ component of manure is reflected in the final LCIA outcomes. For ME, we observed larger uncertainty for results of future scenarios than for the baseline. This is explained by the large uncertainty associated with the estimate of nitrate leaching into water (Table 4), the main contribution to ME, for which future scenarios have a considerably higher standard deviation compared to the baseline. Again, this reflects the different level of confidence in the LCI data used.

\section{Discussion}

In this section we first discuss the results of the case study, where we used primary data for assessment of future yields as recommended by the guidelines (section 4.1) and then we present the recommendations for how to perform LCA on future crop production based on our experience (section 4.2).

\subsection{Case study on Danish spring barley}

The definition of the baseline scenario for spring barley under Danish conditions (step 1) is quite univocal, since national databases (Knowledge Centre for Agriculture, 2013) and published data valid for Denmark (Hamelin et al., 2012) are available and can be used to describe the adopted field operations, as well as the amount and type of fertilizers and pesticides. The choice of LCIA method is more ambiguous; if a method that does not distinguish different value sets, e.g. through the use of cultural perspectives, is selected, then the identification of focus point at impact category level can be performed based on simple normalization or endpoint modelling.

In the identification of alternative scenarios (step 2) we adopted a conservative approach, based on continued use of current management practices and considering only cultivar improvement, since this is expected to be the most relevant adaptation solutions in the case of spring barley (Olesen et al., 2011). In the RERAF experiments, the amount of fertilizer currently applied in the field, was also used when simulating the management practice in the future climate. Therefore we kept the fertilizer application rate constant in the LCI modelling for all future scenarios, as also suggested by Dijkman (2013). However, the influence of a change in fertilizer application rate has been assessed in a sensitivity analysis in Niero et al. (2015b). Pest development and pesticide application are part of the "known unknowns" connected with climate change. In the development of the future scenarios we assumed use of the same type of pesticide as is used today but adjusted treatment index to accommodate for changes in occurrence of pests and in precipitation patterns (Juroszek and von Tiedemann, 2011). However this is a simplification, since we are aware that a change in crop protection is a prominent adaptation measure for barley. Overarching the uncertainty of future pest control practices is the regulatory framework that might be expected to change in the future, as well as the use of new types of pesticides and active ingredients that are not known today.

In step 3, when we compare the baseline scenario with the future scenarios, we can conclude that the impacts caused by future spring barley cultivation in Denmark is overall expected to be higher than today, even when confidence intervals are considered. Only with the use of high-yield cultivars (S2) the impacts could be comparable with the current values. When the central parameter 'future crop yield' is based on secondary data (S5 - based on data from Doltra et al. (2012)), the environmental impacts of future scenarios become even higher for all impact categories, when compared with scenarios, where the crop yield is based on our measured data under the two-factor treatment (S1, S2), and even under extreme event conditions (S3, S4), as reported in Figure 5. These considerations provide a further confirmation of the reliability of the results 
reported in Niero et al. (2015b) that showed that the selection of proper cultivars is one effective way of reducing the environmental impacts of spring barley in the future, and that the gain in terms of crop yield obtained from breeding of high yielding cultivars can be annulled by the effect of extreme weather events. The comparison of scenarios including parameter uncertainty analysis indeed confirms these findings, as well as the significance of the use of primary data for estimating crop yield data.

\subsection{Recommendations}

The choice of cultivars has recently been presented as a cornerstone in securing the future primary production (Challinor et al., 2014), as well as the most effective way for reducing the future environmental impacts of crops, e.g. apple Cerutti et al. (2013). Our results also indicate that adaptation strategies should prioritize the development of cultivars with stability and resilience over a range of different environments, but they also show that the effects that extreme events have on the performance of the optimized cultivars should not be underestimated. Furthermore, crop yield modelling and experiments are subject to their own uncertainties (Ingvordsen, 2014). For example, interactions between $\left[\mathrm{CO}_{2}\right]$, temperature, soil nutrients, $\left[\mathrm{O}_{3}\right]$, pests and weeds are not well understood and therefore most crop models do not include these effects and their interactions. There are also uncertainties associated with the generalization of results of field experiments, since each experiment has been conducted relatively few times under a relatively small range of environmental and management conditions, and usually for a limited number of genotypes (Porter et al., 2014). With our approach we can quantify the expected increased uncertainty through statistical distribution, based on measured data. However, in this paper we only focused on the role of cultivar selection as the adaptation strategy, without including the effect of crop management practices. A discussion of the role of crop management practices such as early sowing for spring barley under future climate change is provided in Niero et al. (2015).

The environmental performance of cultivars is anyway only one of the aspects which need to be included in the design of sustainable food systems. As already discussed by McDevitt and Milà i Canals (2011) in the case of porridge oats from the UK, LCA cannot stand alone in the evaluation of plant breeding programs to improve supply chain sustainability. The first step consists in doing an LCA study, and according to its results take direction to develop breeding strategies, e.g. through a genome association study (Ingvordsen et al., 2015b). In this way different disciplines can be complementary in the analysis of a complex and crucial challenge as adaptation of crop production to climate change. As pointed out by Lobell (2014), many potential changes in agricultural management and technology, including shifts in crop phenology and improved drought and heat tolerance, would help to improve crop productivity, but do not necessarily represent true adaptations.

Our approach is based on a simple step-by-step procedure, which overcomes some of the limitations of the consequential approach, which has mainly been used so far to address LCAs of future scenarios. In the context of climate change, decisions are strictly dependent on the response of natural systems to climatic changes, which cannot be predicted by means of economical or technological models. On the other hand, application of our recommended approach relies on the availability of primary measured data for performance under altered climatic conditions, and this will not always be possible, as primary data of this kind are rarely available.

Our recommended procedure deals with the impacts from future crop production at the LCI level. However, the effect of increased $\mathrm{T}$ and $\left[\mathrm{CO}_{2}\right]$ in the environment will affect also the modelling of the environmental mechanism from inventory to impact assessment level. In the LCIA, e.g. for marine eutrophication, future climatic conditions may alter coastal biological processes rates and the metabolism of coastal organisms, displace species (translation effect), or increase the sensitivity of target species exposed to hypoxia (Brierley 
and Kingsford, 2009; Cosme and Niero, 2015). This aspect has not been addressed in this paper but deserves equal attention.

\section{Conclusions}

We defined a 3-step approach for managing uncertainty in the definition of future LCA scenarios addressing the effect of climate change in crop production. This 3-step approach can be implemented using the tools included in the interpretation step of an LCA. These tools are contribution analysis to identify the focus points in terms of impact categories, unit processes and substances; scenario analysis to determine a range of alternative future scenarios, as well as the most influencing parameters, and finally uncertainty analysis, to account for different levels of confidence in the output data. Our suggestion to reduce the uncertainty in the definition of future scenarios in LCA of crop production addressing the effects of climate change is to rely also on primary data coming from experiments mimicking future climate and not only make use of predictions from yield or quality models. This approach has been tested in the case of spring barley cultivation under Danish conditions, combining primary data on crop yield from experimental scenarios in a climate phytotron, and recommended practice of field operations. It can be replicated for other LCA studies on crop production, if data from experimental facilities are available, e.g. on crop yield, crop quality, crop diseases, weeds and pests under future ambient and extreme conditions. Despite the major role of crop yield on the overall performance of crop production, adaptation to climate change needs to be assessed at the broadest possible level, challenging crop management level, e.g. through changes in the time of sowing and optimization of crop rotations.

This study represents a first step towards the inclusion of the effect of increased temperature and $\left[\mathrm{CO}_{2}\right]$ on LCI of future agricultural systems in terms of crop yield and crop quality, as well as influence on extreme heat-wave, $\mathrm{N}$ leaching and crop diseases, weeds and pests. Future research is needed for the quantification of these effects at the LCIA level, as well as on investigating the role of soil dynamics in LCA.

\section{Acknowledgements}

The authors would like to thank the Nordic Council of Ministers (NordForsk) for funding the project 'Sustainable production in a changing climate', as well as all project partners, in particular Pirjo PeltonenSainio, Marja Jalli, Michael F. Lyngkjær, Rasmus Lund Hjortshøj, Jens Due Jensen and Lars Reitan for the profitable discussions. Furthermore, we would like to thank Teunis J. Dijkman for providing an updated version of PestLCI 2.0.

\section{References}

Alemayehu, F.R., Frenck, G., Linden, L., Mikkelsen, T.N., Jørgensen, R.B., 2013. Can barley (Hordeum vulgare L. s.1.) adapt to fast climate changes? A controlled selection experiment. Genet. Resour. Crop Evol. 61, 151-161. doi:10.1007/s10722-013-0021-1

Alexandratos, N., Bruinsma, J., 2012. World Agriculture towards 2030/2050: the 2012 Revision. ESA Working paper no. 12-03. Rome, FAO.

Audsley, E., Wilkinson, M., 2014. What is the potential for reducing national greenhouse gas emissions from crop and livestock production systems? J. Clean. Prod. 73, 263-268. doi:10.1016/j.jclepro.2014.01.066 
Basset-Mens, C., Kelliher, F.M., Ledgard, S., Cox, N., 2009. Uncertainty of global warming potential for milk production on a New Zealand farm and implications for decision making. Int. J. Life Cycle Assess. 14, 630-638. doi:10.1007/s11367-009-0108-2

Berntsen, J., Petersen, B.M., Olesen, J.E., 2006. Simulating trends in crop yield and soil carbon in a longterm experiment - effects of rising CO2, N deposition and improved cultivation. Plant Soil 287, 235 245. doi:10.1007/s11104-006-9070-y

Blonk Agri-footprint BV, 2014. Agri-footprint. Description of data. V1.0. PJ Gouda (The Netherlands).

Bojacá, C.R., Wyckhuys, K. a. G., Schrevens, E., 2014. Life cycle assessment of Colombian greenhouse tomato production based on farmer-level survey data. J. Clean. Prod. 69, 26-33. doi:10.1016/j.jclepro.2014.01.078

Brierley, A.S., Kingsford, M.J., 2009. Impacts of climate change on marine organisms and ecosystems. Curr. Biol. 19, R602-614. doi:10.1016/j.cub.2009.05.046

Cerutti, A.K., Bruun, S., Donno, D., Beccaro, G.L., Bounous, G., 2013. Environmental sustainability of traditional foods: the case of ancient apple cultivars in Northern Italy assessed by multifunctional LCA. J. Clean. Prod. 52, 245-252. doi:10.1016/j.jclepro.2013.03.029

Chakraborty, S., Newton, a. C., 2011. Climate change, plant diseases and food security: an overview. Plant Pathol. 60, 2-14. doi:10.1111/j.1365-3059.2010.02411.x

Challinor, a. J., Watson, J., Lobell, D.B., Howden, S.M., Smith, D.R., Chhetri, N., 2014. A meta-analysis of crop yield under climate change and adaptation. Nat. Clim. Chang. 4, 287-291.

doi:10.1038/nclimate2153

Ciroth, A., Muller, S., Weidema, B., Lesage, P., 2013. Empirically based uncertainty factors for the pedigree matrix in ecoinvent. Int. J. Life Cycle Assess. doi:10.1007/s11367-013-0670-5

Clausen, S.K., Frenck, G., Linden, L.G., Mikkelsen, T.N., Lunde, C., Jørgensen, R.B., 2011. Effects of Single and Multifactor Treatments with Elevated Temperature, CO2 and Ozone on Oilseed Rape and Barley. J. Agron. Crop Sci. 197, 442-453. doi:10.1111/j.1439-037X.2011.00478.x

Cluzel, F., Yannou, B., Millet, D., Leroy, Y., 2013. Exploitation scenarios in industrial system LCA. Int. J. Life Cycle Assess. 19, 231-245. doi:10.1007/s11367-013-0631-z

Collins, M., Knutti, R., Arblaster, J., Dufresne, J.-L., Fichefet, T., Friedlingstein, P., Gao, X., Gutowski, W., Johns, T., Krinner, G., Shongwe M, Tebaldi C, Weaver AJ, W.M., 2013. Long-term Climate Change: Projections, Commitments and Irreversibility. In Climate Change 2013: The Physical Science Basis. Contribution of Working Group I to the Fifth Assessment Report of the Intergovernmental Panel on Climate Change. Cambridge University Press, Cambridge, United Kingdom and New York, NY, USA,1535 pp.

Colomb, V., Amar, S.A., Mens, C.B., Gac, A., Gaillard, G., Mousset, J., Salou, T., Tailleur, A., Werf, H.M.G. Van Der, 2014. AGRIBALYSE(R), the French LCI Database for agricultural products: high quality data for producers and environmental labelling. Oilseeds fats Crop. Lipids 8-10. doi:http://dx.doi.org/10.1051/ocl/20140047 
Cosme, N., Niero, M., 2015. Marine eutrophication impacts from present and future production of spring barley, in: Submitted to EXPO 2015 Conference, LCA for "Feeding the Planet and Energy for Life", 68 October 2015 in Stresa, Lake Maggiore (Italy).

De Camillis, C., Brandão, M., Zamagni, A., Pennington, D., 2013. Sustainability assessment of futureoriented scenarios : a review of data modelling approaches in Life Cycle Assessment Towards recommendations for policy making and business strategies. European Commission, Joint Research Centre, Institute for Environment and Sustainability, Publications Office of the European Union, Luxemburg. doi:10.2788/95227

De Schryver, A.M., van Zelm, R., Humbert, S., Pfister, S., McKone, T.E., Huijbregts, M. a. J., 2011. Value Choices in Life Cycle Impact Assessment of Stressors Causing Human Health Damage. J. Ind. Ecol. 15, 796-815. doi:10.1111/j.1530-9290.2011.00371.x

Dijkman, T.J., 2013. Modelling of pesticide emissions for Life Cycle Inventory analysis: model development, applications and implications. PhD Thesis. Technical University of Denmark. Denmark.

Dijkman, T.J., Birkved, M., Hauschild, M.Z., 2012. PestLCI 2.0: a second generation model for estimating emissions of pesticides from arable land in LCA. Int. J. Life Cycle Assess. 17, 973-986. doi:10.1007/s11367-012-0439-2

Doltra, J., Lægdsmand, M., Olesen, J.E., 2012. Impacts of projected climate change on productivity and nitrogen leaching of crop rotations in arable and pig farming systems in Denmark. J. Agric. Sci. 152, 75-92. doi:10.1017/S0021859612000846

Fedele, A., Mazzi, A., Niero, M., Zuliani, F., Scipioni, A., 2014. Can the LCA methodology be adopted to support a single farm on its environmental impacts forecast evaluation between conventional and organic production? An Italian case study. J. Clean. Prod. 69, 49-59. doi:10.1016/j.jclepro.2014.01.034

Foley, J. a, Ramankutty, N., Brauman, K. a, Cassidy, E.S., Gerber, J.S., Johnston, M., Mueller, N.D., O'Connell, C., Ray, D.K., West, P.C., Balzer, C., Bennett, E.M., Carpenter, S.R., Hill, J., Monfreda, C., Polasky, S., Rockström, J., Sheehan, J., Siebert, S., Tilman, D., Zaks, D.P.M., 2011. Solutions for a cultivated planet. Nature 478, 337-342. doi:10.1038/nature10452

Frenck, G., van der Linden, L., Mikkelsen, T.N., Brix, H., Jørgensen, R.B., 2011. Increased [CO2] does not compensate for negative effects on yield caused by higher temperature and [O3] in Brassica napus L. Eur. J. Agron. 35, 127-134. doi:10.1016/j.eja.2011.05.004

Frenck, G., van der Linden, L., Mikkelsen, T.N., Brix, H., Jørgensen, R.B., 2013. Response to multigenerational selection under elevated $[\mathrm{CO} 2]$ in two temperature regimes suggests enhanced carbon assimilation and increased reproductive output in Brassica napus L. Ecol. Evol. 3, 1163-1172. doi:10.1002/ece3.523

Frischknecht, R., Büsser, S., Krewitt, W., 2009. Environmental assessment of future technologies: how to trim LCA to fit this goal? Int. J. Life Cycle Assess. 14, 584-588. doi:10.1007/s11367-009-0120-6

Frischknecht, R., Jungbluth, N., Althaus, H.-J., Doka, G., Heck, T., Hellweg, S., Hischier, R., Nemecek, T., Rebitzer, G., Spielmann, M., Wernet, G., 2007. Overview and Methodology. Ecoinvent Report No. 1. Swiss Centre for Life Cycle Inventories. Dübendorf, Switzerland. 
Godfray, H.C.J., Beddington, J.R., Crute, I.R., Haddad, L., Lawrence, D., Muir, J.F., Pretty, J., Robinson, S., Thomas, S.M., Toulmin, C., 2010. Food security: the challenge of feeding 9 billion people. Science 327, 812-8. doi:10.1126/science.1185383

Goedkoop, M., Heijungs, R., Huijbregts, M., De Schryver, A., Struijs, J., R, van Z., 2009. ReCiPe 2008, A life cycle impact assessment method which comprises harmonised category indicators at the midpoint and the endpoint level.

González-García, S., Bacenetti, J., Murphy, R.J., Fiala, M., 2012. Present and future environmental impact of poplar cultivation in the Po Valley (Italy) under different crop management systems. J. Clean. Prod. 26, 56-66. doi:10.1016/j.jclepro.2011.12.020

Hamelin, L., Jørgensen, U., Petersen, B.M., Olesen, J.E., Wenzel, H., 2012. Modelling the carbon and nitrogen balances of direct land use changes from energy crops in Denmark: a consequential life cycle inventory. GCB Bioenergy 4, 889-907. doi:10.1111/j.1757-1707.2012.01174.x

Hayashi, K., Makino, N., Shobatake, K., Hokazono, S., 2014. Influence of scenario uncertainty in agricultural inputs on life cycle greenhouse gas emissions from agricultural production systems: the case of chemical fertilizers in Japan. J. Clean. Prod. 73, 109-115. doi:10.1016/j.jclepro.2013.11.051

Henriksen, H.J., Rosenbom, A., van der Keur, P., Olesen, J.E., Jørgensen, L.J., Kjær, J., Sonnenborg, T., Christensen, O.B., 2012. Prediction of climatic impacts on pesticide leaching to the aquatic environments. Pesticide research no. 143. Danish Ministry of the Environment. Environmental Protection Agency.

Hospido, A., Davis, J., Berlin, J., Sonesson, U., 2009. A review of methodological issues affecting LCA of novel food products. Int. J. Life Cycle Assess. 15, 44-52. doi:10.1007/s11367-009-0130-4

Högy, P., Poll, C., Marhan, S., Kandeler, E., Fangmeier, A., 2013. Impacts of temperature increase and change in precipitation pattern on crop yield and yield quality of barley. Food Chem. 136, 1470-7. doi:10.1016/j.foodchem.2012.09.056

Höjer, M., Ahlroth, S., Dreborg, K.-H., Ekvall, T., Finnveden, G., Hjelm, O., Hochschorner, E., Nilsson, M., Palm, V., 2008. Scenarios in selected tools for environmental systems analysis. J. Clean. Prod. 16, 1958-1970. doi:10.1016/j.jclepro.2008.01.008

Ingvordsen, C.H., 2014. Climate Change Effects to Plant Ecosystems - Resources for Future Barley Breeding. PhD thesis. Technical University of Denmark. Denmark.

Ingvordsen, C.H., Backes, G., Lyngkjær, M.F., Peltonen-Sainio, P., Jahoor, A., Mikkelsen, T.N., Jørgensen, R.B., 2015. Genome-wide association study of production and stability traits in barley cultivated under future climate scenarios. Mol. Breed. 35, 84. doi:10.1007/s11032-015-0283-8

Ingvordsen, C.H., Backes, G., Lyngkjær, M.F., Peltonen-Sainio, P., Jensen, J.D., Jalli, M., Jahoor, A., Rasmussen, M., Mikkelsen, T.N., Stockmarr, A., Jørgensen, R.B., 2015. Significant decrease in yield under future climate conditions: Stability and production of 138 spring barley accessions. Eur. J. Agron. 63, 105-113. doi:10.1016/j.eja.2014.12.003

IPCC, 2006. 2006 IPCC Guidelines for National Greenhouse Gas Inventories, Prepared by the National Greenhouse Gas Inventories Programme. IGES, Japan. 
IPCC, 2013. Climate Change 2013 The Physical Science Basis Working Group I Contribution to the Fifth Assessment Report of the Intergovernmental Panel on Climate Change Edited by. Cambridge University Press, Cambridge, United Kingdom and New York, NY, USA, 1535pp.

IPCC, 2014a. Climate Change 2014: Impacts, Adaptation, and Vulnerability. Contribution of Working Group II to the Fifth Assessment Report of the Intergovernmental Panel on Climate Change.

IPCC, 2014b. Summary for Policymakers; Climate Change 2014: Mitigation of Climate Change. Contribution of Working Group III to the Fifth Assessment Report of the Intergovernmental Panel on Climate Change.

Jensen, N.H., Veihe, a., 2009. Modelling the effect of land use and climate change on the water balance and nitrate leaching in eastern Denmark. J. Land Use Sci. 4, 53-72. doi:10.1080/17474230802645832

Juroszek, P., von Tiedemann, a., 2011. Potential strategies and future requirements for plant disease management under a changing climate. Plant Pathol. 60, 100-112. doi:10.1111/j.13653059.2010.02410.x

Knowledge Centre for Agriculture, 2013. Dyrkningsvejledning for vårbyg. English title: Growing Instructions for spring barley. https://www.landbrugsinfo.dk (last accessed 24 Feb 2014).

Knudsen, M.T., Meyer-Aurich, A., Olesen, J.E., Chirinda, N., Hermansen, J.E., 2014. Carbon footprints of crops from organic and conventional arable crop rotations - using a life cycle assessment approach. J. Clean. Prod. 64, 609-618. doi:10.1016/j.jclepro.2013.07.009

Korsaeth, A., Henriksen, T.M., Roer, A.-G., Hammer Strømman, A., 2014. Effects of regional variation in climate and SOC decay on global warming potential and eutrophication attributable to cereal production in Norway. Agric. Syst. 127, 9-18. doi:10.1016/j.agsy.2013.12.007

Langevin, B., Basset-Mens, C., Lardon, L., 2010. Inclusion of the variability of diffuse pollutions in LCA for agriculture: the case of slurry application techniques. J. Clean. Prod. 18, 747-755. doi:10.1016/j.jclepro.2009.12.015

Lloyd, S.M., Ries, R., 2007. and Analyzing Uncertainty in Life-Cycle Assessment A Survey of Quantitative Approaches 11.

Lobell, D.B., 2014. Climate change adaptation in crop production: Beware of illusions. Glob. Food Sec. 3, 72-76. doi:10.1016/j.gfs.2014.05.002

McDevitt, J.E., Milà i Canals, L., 2011. Can life cycle assessment be used to evaluate plant breeding objectives to improve supply chain sustainability? A worked example using porridge oats from the UK. Int. J. Agric. Sustain. 9, 484-494. doi:10.1080/14735903.2011.584473

Middelaar, C.E., Cederberg, C., Vellinga, T. V., Werf, H.M.G., Boer, I.J.M., 2012. Exploring variability in methods and data sensitivity in carbon footprints of feed ingredients. Int. J. Life Cycle Assess. 18, 768 782. doi:10.1007/s11367-012-0521-9

Mikkelsen, B.L., Jørgensen, R.B., Lyngkjaer, M.F., 2014. Complex interplay of future climate levels of CO 2 , ozone and temperature on susceptibility to fungal diseases in barley. Plant Pathol. n/a-n/a. doi:10.1111/ppa.12272 
Münster, M., Finnveden, G., Wenzel, H., 2013. Future waste treatment and energy systems - examples of joint scenarios. Waste Manag. 33, 2457-64. doi:10.1016/j.wasman.2013.07.013

Nemecek, T., Bengoa, X., Lansche, J., Mouron, P., Rossi, V., Humbert, S., 2014. Methodological Guidelines for the Life Cycle Inventory of Agricultural Products. Version 2.0 July 2014. Lausanne and Zurich,Switzerland.

Nemecek, T., Weiler, K., Plassmann, K., Schnetzer, J., Gaillard, G., Jefferies, D., García-Suárez, T., King, H., Milà i Canals, L., 2012. Estimation of the variability in global warming potential of worldwide crop production using a modular extrapolation approach. J. Clean. Prod. 31, 106-117. doi:10.1016/j.jclepro.2012.03.005

Niero, M., Di Felice, F., Ren, J., Manzardo, A., Scipioni, A., 2014a. How can a life cycle inventory parametric model streamline life cycle assessment in the wooden pallet sector? Int. J. Life Cycle Assess. 19, 901-918. doi:10.1007/s11367-014-0705-6

Niero, M., Ingvordsen, C.H., Peltonen-Sainio, P., Jalli, M., Lyngkjær, M.F., Hauschild, M.Z., Jørgensen, R.B., 2015. Eco-efficient production of spring barley in a changed climate: A Life Cycle Assessment including primary data from future climate scenarios. Agric. Syst. 136, 46-60. doi:10.1016/j.agsy.2015.02.007

Niero, M., Pizzol, M., Bruun, H.G., Thomsen, M., 2014b. Comparative life cycle assessment of wastewater treatment in Denmark including sensitivity and uncertainty analysis. J. Clean. Prod. 68, 25-35. doi:10.1016/j.jclepro.2013.12.051

Odegard, I.Y.R., van der Voet, E., 2014. The future of food - Scenarios and the effect on natural resource use in agriculture in 2050. Ecol. Econ. 97, 51-59. doi:10.1016/j.ecolecon.2013.10.005

Olesen, J.E., 2008. Climate Change and CO 2 Effects on Productivity of Danish Agricultural Systems. J. Crop Improv. 13, 257-274. doi:10.1300/J411v13n01

Olesen, J.E., Bindi, M., 2002. Consequences of climate change for European agricultural productivity, land use and policy. Eur. J. Agron. 16, 239-262. doi:10.1016/S1161-0301(02)00004-7

Olesen, J.E., Børgesen, C.D., Elsgaard, L., Palosuo, T., Rötter, R.P., Skjelvåg, a O., Peltonen-Sainio, P., Börjesson, T., Trnka, M., Ewert, F., Siebert, S., Brisson, N., Eitzinger, J., van Asselt, E.D., Oberforster, M., van der Fels-Klerx, H.J., 2012. Changes in time of sowing, flowering and maturity of cereals in Europe under climate change. Food Addit. Contam. Part A. Chem. Anal. Control. Expo. Risk Assess. 29, 1527-42. doi:10.1080/19440049.2012.712060

Olesen, J.E., Trnka, M., Kersebaum, K.C., Skjelvåg, a. O., Seguin, B., Peltonen-Sainio, P., Rossi, F., Kozyra, J., Micale, F., 2011. Impacts and adaptation of European crop production systems to climate change. Eur. J. Agron. 34, 96-112. doi:10.1016/j.eja.2010.11.003

Pesonen, H.-L., Ekvall, T., Fleischer, G., Huppes, G., Jahn, C., Klos, Z.S., Rebitzer, G., Sonnemann, G.W., Tintinelli, A., Weidema, B.P., Wenzel, H., 2000. Framework for scenario development in LCA. Int. J. Life Cycle Assess. 5, 21-30. doi:10.1007/BF02978555

Petersen, B.M., 2010. A Model for the Carbon Dynamics in Agricultural, Mineral Soils. Technical Report. Aarhus University. www.agrsci.dk/c-tool. 
Petersen, B.M., Knudsen, M.T., Hermansen, J.E., Halberg, N., 2013. An approach to include soil carbon changes in life cycle assessments. J. Clean. Prod. 52, 217-224. doi:10.1016/j.jclepro.2013.03.007

Plevin, R.J., Delucchi, M. a., Creutzig, F., 2014. Using Attributional Life Cycle Assessment to Estimate Climate-Change Mitigation Benefits Misleads Policy Makers. J. Ind. Ecol. 13, 73-83. doi:10.1111/jiec. 12074

Porter, J.R., Xie, L., Challinor, A., Cochrane, K., Howden, S., Iqbal, M., Lobell, D., Travasso, M., 2014. Food security and food production systems. In: Climate Change 2014: Impacts, Adaptation, and Vulnerability. Part A: Global and Sectoral Aspects. Contribution of Working Group II to the Fifth Assessment Report of the Intergovernmental Panel on Climate Chan. Cambridge University Press, Cambridge, United Kingdom and New York, NY, USA, pp. 485-533.

Renzulli, P.A., Bacenetti, J., Graziella, B., Fusi, A., Ioppolo, G., Niero, M., Proto, M., Salomone, R., Sica, D., Supino, S., 2015. Life Cycle Assessment in the Cereal and Derived Products Sector, in: Notarnicola, B., Salomone, R., Petti, L., Renzulli, P.A., Roma, R., Cerrutti, A.K. (Eds.), Life Cycle Assessment in the Agri-Food Sector. Case Studies, Methodological Issues and Best Practices. Springer, pp. 185-250.

Rockström, J., Steffen, W., Noone, K., Persson, A., Chapin, F.S., Lambin, E.F., Lenton, T.M., Scheffer, M., Folke, C., Schellnhuber, H.J., Nykvist, B., de Wit, C.A., Hughes, T., van der Leeuw, S., Rodhe, H., Sörlin, S., Snyder, P.K., Costanza, R., Svedin, U., Falkenmark, M., Karlberg, L., Corell, R.W., Fabry, V.J., Hansen, J., Walker, B., Liverman, D., Richardson, K., Crutzen, P., Foley, J.A., 2009. A safe operating space for humanity. Nature 461, 472-475. doi:10.1038/461472a

Roer, A.-G., Korsaeth, A., Henriksen, T.M., Michelsen, O., Strømman, A.H., 2012. The influence of system boundaries on life cycle assessment of grain production in central southeast Norway. Agric. Syst. 111, 75-84. doi:10.1016/j.agsy.2012.05.007

Röder, M., Thornley, P., Campbell, G., Bows-Larkin, A., 2014. Emissions associated with meeting the future global wheat demand: A case study of UK production under climate change constraints. Environ. Sci. Policy 39, 13-24. doi:10.1016/j.envsci.2014.02.002

Rötter, R.P., Carter, T.R., Olesen, J.E., Porter, J.R., 2011. Crop-climate models need an overhaul. Nat. Clim. Chang. 1, 175-177. doi:10.1038/nclimate1152

Rötter, R.P., Palosuo, T., Kersebaum, K.C., Angulo, C., Bindi, M., Ewert, F., Ferrise, R., Hlavinka, P., Moriondo, M., Nendel, C., Olesen, J.E., Patil, R.H., Ruget, F., Takáč, J., Trnka, M., 2012. Simulation of spring barley yield in different climatic zones of Northern and Central Europe: A comparison of nine crop models. F. Crop. Res. 133, 23-36. doi:10.1016/j.fcr.2012.03.016

Rötter, R.P., Palosuo, T., Pirttioja, N.K., Dubrovsky, M., Salo, T., Fronzek, S., Aikasalo, R., Trnka, M., Ristolainen, A., Carter, T.R., 2011. What would happen to barley production in Finland if global warming exceeded $4^{\circ} \mathrm{C}$ ? A model-based assessment. Eur. J. Agron. 35, 205-214. doi:10.1016/j.eja.2011.06.003

Soussana, J.-F., 2014. Research priorities for sustainable agri-food systems and life cycle assessment. J. Clean. Prod. 73, 19-23. doi:10.1016/j.jclepro.2014.02.061

Spielmann, M., Scholz, R.W., Tietje, O., Haan, P. De, 2005. Scenario Modelling in Prospective LCA of Transport Systems Application of Formative Scenario Analysis. Int. J. Life Cycle Assess. 10, 325-335. 
Stockmann, U., Adams, M. a., Crawford, J.W., Field, D.J., Henakaarchchi, N., Jenkins, M., Minasny, B., McBratney, A.B., Courcelles, V.D.R. De, Singh, K., Wheeler, I., Abbott, L., Angers, D. a., Baldock, J., Bird, M., Brookes, P.C., Chenu, C., Jastrow, J.D., Lal, R., Lehmann, J., O’Donnell, A.G., Parton, W.J., Whitehead, D., Zimmermann, M., 2013. The knowns, known unknowns and unknowns of sequestration of soil organic carbon. Agric. Ecosyst. Environ. 164, 80-99. doi:10.1016/j.agee.2012.10.001

Suh, S., Yang, Y., 2014. On the uncanny capabilities of consequential LCA. Int. J. Life Cycle Assess. doi:10.1007/s11367-014-0739-9

Treyer, K., Bauer, C., Simons, A., 2014. Human health impacts in the life cycle of future European electricity generation. Energy Policy 1-14. doi:10.1016/j.enpol.2014.03.034

Trnka, M., Olesen, J.E., Kersebaum, K.C., Skjelvåg, a. O., Eitzinger, J., Seguin, B., Peltonen-Sainio, P., Rötter, R., Iglesias, A., Orlandini, S., Dubrovský, M., Hlavinka, P., Balek, J., Eckersten, H., Cloppet, E., Calanca, P., Gobin, a., Vučetić, V., Nejedlik, P., Kumar, S., Lalic, B., Mestre, a., Rossi, F., Kozyra, J., Alexandrov, V., Semerádová, D., Žalud, Z., 2011. Agroclimatic conditions in Europe under climate change. Glob. Chang. Biol. 17, 2298-2318. doi:10.1111/j.1365-2486.2011.02396.x

Van Zelm, R., Larrey-Lassalle, P., Roux, P., 2014. Bridging the gap between life cycle inventory and impact assessment for toxicological assessments of pesticides used in crop production. Chemosphere 100, 175-81. doi:10.1016/j.chemosphere.2013.11.037

Virtanen, Y., Sinkko, T., 2012. Evolution of the Total Environmental Impact of the Barley Malt Beer Chain in Finland Total life cycle environmental impact assessment of Finnish beer was updated and analysed for changes over. Brew. Sci. 65, 60-64.

White, J.W., Hoogenboom, G., Kimball, B. a., Wall, G.W., 2011. Methodologies for simulating impacts of climate change on crop production. F. Crop. Res. 124, 357-368. doi:10.1016/j.fcr.2011.07.001 